\title{
Deletion of Stim1 in hypothalamic arcuate nucleus Kiss1 neurons potentiates synchronous GCaMP activity and protects against diet-induced obesity
}

\author{
Jian Qiu ${ }^{a}$, Todd L. Stincic ${ }^{a}$, Martha A. Bosch ${ }^{a}$, Ashley M. Connors ${ }^{a}$, Stefanie Kaech Petrie ${ }^{b}$, Oline K. \\ Rønnekleiv ${ }^{a, c}$, Martin J. Kelly ${ }^{a, c}$
}

Abbreviated title: Deletion of Stim1 of arcuate Kiss1 neurons potentiates the synchronous GCamP6 activity

${ }^{a}$ Department of Chemical Physiology and Biochemistry, Oregon Health and Science University, Portland, United States

bJungers Center for Neurosciences Research, Oregon Health and Science University, Portland, United States 'Division of Neuroscience, Oregon National Primate Research Center, Oregon Health and Science University, Beaverton, United States

Co-corresponding Authors:

Jian Qiu, Ph.D. and Martin J. Kelly, Ph.D.

Department of Chemical Physiology and Biochemistry

Oregon Health and Science University

3181 SW Sam Jackson Park Road

Portland, Oregon, 97239, United States

Tel: 503-494-5835

E-mail: qiuj@ohsu.edu or kellym@ohsu.edu

Number of Pages:

Number of Figures: 7, Tables: 1, multimedia: 2,

Number of words for abstract: 250, introduction: 650, and discussion: 1500.

Conflict of interest statement: The authors declare that no competing interests exist.

Acknowledgements: This research was funded by National Institute of Health (NIH) grants: R01-NS043330 (OKR), R01-NS038809 (MJK) and R01-DK068098 (OKR and MJK). Confocal microscopy was supported by a P30 NS061800 (PI, S Aicher) grant. We thank Mr. Daniel Johnson for his technical support. 


\section{Abstract}

2 Kisspeptin (Kiss1) neurons are essential for reproduction, but their role in the control of energy balance and other

3 homeostatic functions remains unclear. High frequency firing of hypothalamic arcuate Kiss1 (Kiss $\left.1^{\text {ARH }}\right)$ neurons

4 releases kisspeptin into the median eminence, and neurokinin B (NKB) and dynorphin onto neighboring Kiss $1^{\mathrm{ARH}}$

5 neurons to generate a slow excitatory postsynaptic potential (EPSP) mediated by TRPC5 channels that entrains

6 intermittent, synchronous firing of Kiss $1^{\text {ARH }}$ neurons. High frequency optogenetic stimulation of Kiss $1^{\text {ARH }}$ neurons

7 releases glutamate to excite the anorexigenic proopiomelanocortin (POMC) neurons and inhibit the orexigenic

8 neuropeptide Y/agouti-related peptide (AgRP) neurons via metabotropic glutamate receptors. At the molecular

9 level, the endoplasmic reticulum calcium-sensing protein stromal interaction molecule 1 (STIM1) is critically

10 involved in the regulation of neuronal $\mathrm{Ca}^{2+}$ signaling and neuronal excitability through its interaction with plasma

11 membrane calcium (e.g., TRPC) channels. 17ß-estradiol (E2) downregulates Stim1 mRNA expression in female

12 arcuate neurons. Therefore, we hypothesized that deletion of Stim1 in Kiss $1{ }^{\mathrm{ARH}}$ neurons would increase neuronal

13 excitability and their synchronous firing, which ultimately would affect energy homeostasis. Using optogenetics

14 in combination with whole-cell recording and GCaMP6 imaging in slices, we discovered that the deletion of Stim1

15 in Kiss1 neurons significantly increased the amplitude of the slow EPSP and augmented synchronous [Ca $\left.{ }^{2+}\right]$

16 oscillations in Kiss $1^{\mathrm{ARH}}$ neurons. Deletion of Stim1 in Kiss $1^{\mathrm{ARH}}$ neurons amplified the actions of NKB and

17 protected ovariectomized female mice from developing obesity and glucose intolerance with high-fat dieting.

18 Therefore, STIM1 appears to play a critical role in regulating synchronous firing of Kiss $1^{\text {ARH }}$ neurons, which

19 ultimately affects energy homeostasis.

\section{Significance Statement}

21 Hypothalamic arcuate kisspeptin (Kiss $1^{\mathrm{ARH}}$ ) neurons are essential for stimulating the pulsatile release of gonadotropin releasing hormone $(\mathrm{GnRH})$ and maintaining fertility. However, Kiss $1^{\mathrm{ARH}}$ neurons appear to be a

23 key player in coordinating energy balance with reproduction. The regulation of calcium channels and hence 24 calcium signaling is critically dependent on the endoplasmic reticulum calcium-sensing protein stromal 25 interaction molecule 1 (STIM1), which interacts with the plasma membrane calcium channels. We have 26 conditionally deleted Stim1 in Kiss $1^{\mathrm{ARH}}$ neurons and found that it significantly increased the excitability of 
Kiss $1^{\mathrm{ARH}}$ neurons and protected ovariectomized female mice from developing obesity and glucose intolerance with high-fat dieting.

\section{Introduction}

Nutrition and reproduction are inextricably linked across all mammalian species, i.e., high circulating concentrations of $17 \beta$-estradiol (E2) during the late follicular phase of the reproductive cycle correlate with reduced food intake (Czaja, 1978; Asarian and Geary, 2006; Roepke et al., 2010). However, we are just beginning to understand the central mechanisms by which E2 feedback coordinates reproduction and energy balance (Castellano and Tena-Sempere, 2013; Nestor et al., 2014; Navarro, 2020). Kisspeptin neurons in the hypothalamic arcuate nucleus (Kiss $1^{\mathrm{ARH}}$ neurons) appear to be critical for coordinating these two homeostatic processes. Firstly, Kiss1 and its G protein-coupled receptor (GPR54) are essential for pubertal development and reproductive function (Kuohung and Kaiser, 2006). Mutations in Kiss1 or GPR54 cause hypogonadotropic hypogonadism in humans (De Roux et al., 2003; Seminara et al., 2003; Topaloglu et al., 2012), and deletion of Kiss 1 or GPR54 causes defective sexual development and reproductive failure in mice (Seminara et al., 2003; d'Anglemont de Tassigny et al., 2007). These effects on fertility are directly dependent on Kiss1/GPR54 signaling in gonadotropin-releasing hormone (GnRH) neurons (Han et al., 2005; Pielecka-Fortuna et al., 2008; Zhang et al., 2008). Moreover, Kiss1 signaling appears to be also important for normal metabolism and glucose homeostasis. GPR54 deletion in female, but not male, mice causes severe obesity, reduced metabolism, glucose intolerance and hyperleptinemia (Tolson et al., 2014; Tolson et al., 2019). Also, Kiss $1^{\text {ARH }}$ neurons are directly depolarized/excited by leptin (Qiu et al., 2011) and insulin (Qiu et al., 2014), so they are quite possibly the key neurons involved in conveying metabolic information to GnRH neurons.

High frequency optogenetic stimulation of Kiss $1^{\mathrm{ARH}}$ neurons expressing channel rhodopsin (ChR2) generates pulsatile release of LH (Clarkson et al., 2017). Kiss $1^{\mathrm{ARH}}$ neurons co-express neurokinin B (NKB) and dynorphin (Goodman et al., 2007; Navarro et al., 2009) and high-frequency firing $(10-20 \mathrm{~Hz})$ of these neurons co-releases 
2016). NKB binds to tachykinin 3 receptor (TacR3) in neighboring Kiss $1^{\text {ARH }}$ neurons to activate canonical

transient receptor potential 5 (TRPC5) channels to cause a robust depolarization (slow EPSP), whereas co-

released dynorphin feeds back to bind to presynaptic K-opioid receptors to limit the release of NKB to discrete

bursts of activity (Qiu et al., 2016). The co-release of the two peptide neurotransmitters coordinates the synchronous firing of Kiss $1^{\mathrm{ARH}}$ neurons that drives the pulsatile release of $\mathrm{GnRH}$ into the median eminence (Qiu et al., 2016; Clarkson et al., 2017).

The activity of TRPC channels is modulated by stromal-interaction molecule 1 (STIM1), which is localized to the endoplasmic reticulum (ER) membrane of cells, and its N-terminal domain contains an EF-hand that senses changes in ER calcium concentrations and maintains intracellular $\mathrm{Ca}^{2+}$ homeostasis through storeoperated $\mathrm{Ca}^{2+}$ entry (SOCE) (Salido et al., 2011). Upon depletion of ER $\mathrm{Ca}^{2+}$, STIM1 oligomerizes and then interacts with plasma membrane calcium (TRPC) channels (Yuan et al., 2007; Salido et al., 2011). Phosphorylation of STIM1 is required for oligomerization, and E2 inhibits the phosphorylation of STIM1 and its interaction with plasma membrane Orai and TRPC channels and hence store-operated $\mathrm{Ca}^{2+}$ entry (Yuan et al., 2007; Salido et al., 2011). Under normal physiological conditions, TRPC5 channels are coupled to plasma membrane receptors (Qiu et al., 2010; Qu et al., 2014; Gao et al., 2017), but in cellular stressed states (e.g., inflammation, obesity) TRPC5 channels may associate with STIM1 to replete ER $\mathrm{Ca}^{2+}$ stores (Birnbaumer, 2009;

Qiu et al., 2018b). E2 maintains the excitatory effects of insulin in POMC neurons, mediated by TRPC5 channel opening, by downregulating Stim1 expression, thereby protecting against insulin resistance in obese females (Qiu et al., 2018b). E2 also downregulates Stim1 expression in the ARH of female guinea pigs, indicating that this interaction is more widespread in the ARH. Therefore, we hypothesized that deletion of Stim1 in Kiss $1^{\text {ARH }}$ neurons would augment TacR3 mediated depolarization via TRPC5 channels to ultimately drive synchronous 76 firing of the "pulse generator Kiss $1{ }^{\mathrm{ARH}}$ neurons.

\section{Materials and Methods}

Animals 
All animal procedures were conducted at Oregon Health and Science University (OHSU) according to the

National Institutes of Health Guide for the Care and Use of Laboratory Animals and with approval from the OHSU

$84 \quad$ Animal Care and Use Committee.

We used female mice in all of the experiments. Kiss $1^{\text {Cre:GFP }}$ (v2) mice (Dr. Richard D. Palmiter; University of Washington; PMID: 29336844) (Padilla et al., 2018) were housed under constant temperature $\left(21-23^{\circ} \mathrm{C}\right)$ and

12-h light, 12-h dark cycle schedule (lights on at 0600 and lights off at $1800 \mathrm{~h}$ ), with free access to food (Lab

Diets 5LOD) and water. Kiss $1^{\text {Cre:GFP }}$ mice were used for viral injection to express ChR2 or GCaMP6s in Kiss $1^{\text {ARH }}$

neurons or they were crossed with heterozygous Ai32 mice (RRID:IMSR_JAX:024109, C57BL/6 background)

purchased from The Jackson Laboratory. These Ai32 mice carry the ChR2 (H134R)-EYFP gene in their

Gt(ROSA)26Sor locus (Madisen et al., 2012). The gene is separated from its CAG promoter by a loxP-flanked transcriptional STOP cassette, allowing its expression in a Cre-dependent manner. To test for this we dispersed

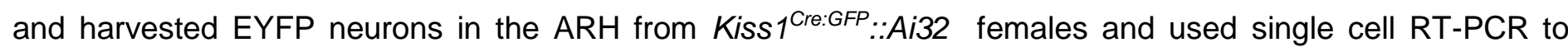
determine Kiss1 mRNA expression as described below and according to previous published methods (Bosch et al., 2013). Data from 126 ARH ${ }^{\text {EYFP }}$ neurons from 6 Kiss $1^{\text {Cre:GFP }:: A i 32 ~ f e m a l e s ~ d o c u m e n t e d ~ t h a t ~} 99 \%$ of the EYFP neurons expressed Kiss1.

To generate mice with conditional knockout of Stim 1 in Kiss 1 neurons $\left(S t i m 1^{\text {kko }}\right)$, we first crossed Kiss $1^{\text {Cre/+ }}$ (v2) males (Padilla et al., 2018) with Stim1 1oxP/loxP females (Jackson Laboratory Stock \#023350, RRID:IMSR_JAX:023350, (Oh-hora et al., 2008)). This cross knocks out Stim1 through excising exon 2 (Ohhora et al., 2008) of the floxed Stim1 gene in cells in which Cre is expressed under the control of a promoter specific for the expression of Kiss1 (Padilla et al., 2018; Qiu et al., 2018a). The F1 mice produced were

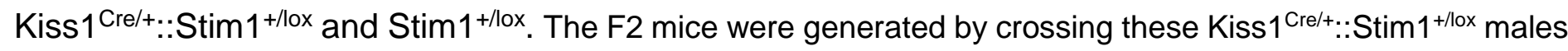
with Stim $1^{\text {loxPllox }}$ females. Approximately $25 \%$ of the offspring were Kiss $1^{\text {Crel }+: . S t i m} 1^{\text {loxllox }}$ such that Stim 1 was deleted in Kiss1 cells (Stim $1^{\mathrm{KKO}}$ ), and all the Stim1 knock-out mice were seen at the expected frequency and viable throughout adulthood. We used Kiss $1^{\mathrm{Cre} /+}$ mice as controls. To increase the yield of Stim 1 knock-out mice, 


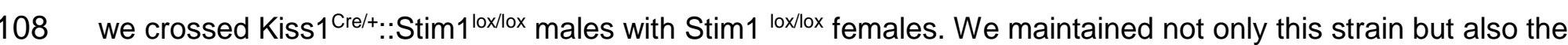

109 Kiss $1^{\text {Cre/+ }}$ strain at the same time. Genotypes for Stim1 were determined using forward primer JAX\#18885 (5'-

110 CGA TGG TCT CAC GGT CTC TA-3') and reverse primer JAX\#18886 (5'-GCT CTG CTG ACC TGG AAC TA-

111 3'), which distinguished between lox/lox, lox/+, and +/+ genotypes. Cre genotypes were determined using

forward primer 5'-GCG GTC TGG CAG TAA AAA CTA TC3'- and reverse primer 5'-TTC CAT GAG TGA ACG

AAC CTG G-3', which distinguished between carriers and non-carriers of the Cre allele.

Puberty onset and estrous cyclicity

To determine whether deleting Stim1 in Kiss1-expressing neurons might impact fertility, we evaluated female Stim $1^{k k o}$ mice and wild type (WT) female littermates for pubertal onset and estrous cyclicity. For breeding, male and female mice were mated at 1:1, and the number of pups per litter was counted. The Stim $1^{\text {kko }}$ mice showed similar fecundity as control mice. Puberty onset in females was assessed by monitoring for vaginal opening daily between 0900 and $1000 \mathrm{hr}$ starting at 3 weeks of age. For estrous cycle studies, Stim $1^{\text {kko }}$ and Kiss $1^{\text {Cre:GFP }}$ female mice were group housed and were habituated to handling for at least one week by the same investigator prior to estrous cycle monitoring. Vaginal lavage was performed daily for 13 consecutive days between 0900 and 1000 hr. Cytology was evaluated using a light microscope and scored as diestrus, proestrus or estrus as previously described (Qiu et al., 2018a). The Number of estrous and diestrous days were counted for each animal and used for statistical analysis (Mann-Whitney U-test).

\section{Gonadectomy}

At least 7 days prior to each experiment, ovaries were removed as described previously while under inhalant isofluorane anesthesia (Piramal Enterprises Limited, Andhra Pradesh, India) (Qiu et al., 2018a). Each mouse received analgesia (Carprofen; $5 \mathrm{mg} / \mathrm{kg}$; subcutaneous) immediately after a surgery for relief of postoperative pain. 
For the metabolic studies, Stim $1^{k k o}$ and Kiss 1 littermate control females were ovariectomized at 2-4 months of age and put on a high fat diet (HFD; 45\% kcal from fat; Research Diets, New Brunswick, NJ; D12451) for eight weeks. Mice were group housed (because of COVID-19 restrictions) and individually weighed every week. The evening prior to the glucose tolerance test (GTT), all mice were assessed for body composition (fat and lean mass) using an EchoMRI 4-in-1-500 Body Composition Analyzer (Houston, TX).

For GTT, age matched Kiss $1^{\text {Cre }}$ and Stim $1^{\text {kko }}$ mice were fasted overnight for $15-\mathrm{h}$, and baseline glucose levels measured with the aid of an Accu-Check Advantage blood glucose meter (Roche) using blood collected from the tail vein. All mice were then injected intraperitoneally with glucose $(1 \mathrm{mg} / \mathrm{g}$ lean mass as determined by EchoMRI) in sterile PBS and blood glucose levels were measured 15, 30, 60, 90, and 120 min after injection. The glucose clearance (area under the curve) was calculated based on the glucose baseline levels at 0 min (Ayala et al., 2010).

\section{AAV delivery to Kiss $1^{\text {Cre:GFP }}$ and Stim $1^{\text {kko }}$ mice}

Fourteen to twenty-one days prior to each experiment, Kiss $1^{\text {Cre:GFP }}$ mice or Stim $1^{\text {kko }}$ mice (>60 days old) received bilateral ARH injections of a Cre-dependent adeno-associated viral (AAV; serotype 1) vector encoding ChR2-mCherry (AAV1-Ef1a-DIO-ChR2: mCherry) or ChR2-YFP (AAV1-Ef1a-DIO-ChR2:YFP, Dr. Stephanie L. Padilla; University of Washington; PMID: 25429312) or GCaMP6s (AAV9-Syn-Flex-GCaMP6s-WPRE-SV40; Addgene, \# 100845-AAV9). Using aseptic techniques, anesthetized female mice ( $1.5 \%$ isoflurane $\left./ \mathrm{O}_{2}\right)$ received a medial skin incision to expose the surface of the skull. The glass pipette (Drummond Scientific \#3-000-203$\mathrm{G} / \mathrm{X}$; Broomall, PA) with a beveled tip (diameter $=45 \mu \mathrm{m}$ ) was filled with mineral oil, loaded with an aliquot of AAV using a Nanoject II (Drummond Scientific). ARH injection coordinates were anteroposterior (AP): $-1.20 \mathrm{~mm}$, mediolateral (ML): $\pm 0.30 \mathrm{~mm}$, dorsoventral (DL): $-5.80 \mathrm{~mm}$ (surface of brain $\mathrm{z}=0.0 \mathrm{~mm}$ ); $500 \mathrm{nl}$ of the AAV $\left(2.0 \times 10^{12}\right.$ particles $\left./ \mathrm{ml}\right)$ was injected $(100 \mathrm{nl} / \mathrm{min})$ into each position, left in place for $10 \mathrm{~min}$ post-injection, then the pipette was slowly removed from the brain. The skin incision was closed using skin adhesive, and each mouse received analgesia (Carprofen; $5 \mathrm{mg} / \mathrm{kg}$ ) for two days post-operation. 
Electrophysiology

Coronal brain slices $(250 \mu \mathrm{m})$ containing the $\mathrm{ARH}$ from gonadectomized females were prepared as previously described (Qiu et al., 2003). Whole-cell, patch recordings were performed in voltage clamp and current clamp using an Olympus BX51W1 upright microscope equipped with video-enhanced, infrareddifferential interference contrast (IR-DIC) and an Exfo X-Cite 120 Series fluorescence light source. Electrodes were fabricated from borosilicate glass (1.5 mm outer diameter; World Precision Instruments, Sarasota, FL) and filled with a normal internal solution (in $\mathrm{mM}$ ): 128 potassium gluconate, $10 \mathrm{NaCl}, 1 \mathrm{MgCl}_{2}, 11 \mathrm{EGTA}, 10 \mathrm{HEPES}$, 3 ATP, and 0.25 GTP (pH was adjusted to 7.3-7.4 with 1N KOH, 290-300 mOsm). Pipette resistances ranged from 3-5 M $\Omega$. In whole cell configuration, access resistance was less than $20 \mathrm{M} \Omega$; access resistance was $80 \%$ compensated. For some experiments measuring the ramp current-voltage (I-V) relationship, $\mathrm{K}^{+}$-gluconate in the normal internal solution was replaced with $\mathrm{Cs}^{+}$-gluconate $(\mathrm{pH} 7.35$ with $\mathrm{CsOH})$, and the extracellular solution contained $\mathrm{Na}^{+}, \mathrm{K}^{+}, \ln (\mathrm{HCN}), \mathrm{Ca}^{2+}$, and $\mathrm{GABA}_{A}$ channel blockers (in mm: $\mathrm{NaCl}, 126$; 4-aminopyridine, 5; $\mathrm{KCl}, 2.5$; $\mathrm{MgCl}_{2}, 1.2 ; \mathrm{CsCl}, 2 ; \mathrm{CaCl}_{2}, 1.4 ; \mathrm{CoCl}_{2}$, 1; nifedipine, 0.01; HEPES, 20; $\mathrm{NaOH}, 8 ;$ glucose, 10; tetrodotoxin, 0.001; picrotoxin, 0.1). For optogenetic stimulation, a light-induced response was evoked using a light-emitting diode (LED) $470 \mathrm{~nm}$ blue light source controlled by a variable 2A driver (ThorLabs, Newton, NJ) with the light path delivered directly through an Olympus 40 water-immersion lens. High fidelity response to light (470 $\mathrm{nm})$ stimulation of Kiss $1^{\mathrm{ARH}}:: \mathrm{ChR} 2-\mathrm{mCherry}$ expressing neurons was observed, and both evoked inward currents (in voltage clamp, $V_{\text {hold }}=-60 \mathrm{mV}$ ) or depolarization (in current clamp) were measured. Electrophysiological signals were amplified with an Axopatch 200A and digitized with Digidata 1322A (Molecular Devices, Foster City, CA), and the data were analyzed using p-Clamp software (RRID:SCR_011323, version 9.2, Molecular Devices). The amplitude of the slow EPSP was measured after low pass filtering in order to eliminate the barrage of action potentials riding on the depolarization. The liquid junction potential was corrected for all data analysis.

\section{Calcium imaging}

For calcium imaging, brain slices were placed in a $\mathrm{RC}-22 \mathrm{C}$ slide recording chamber (Harvard/Warner Instruments) and imaged on an inverted Nikon TiE microscope equipped with a Yokogawa CSU-W1 spinning 
disk confocal head, integrated under NIS Elements v4.20 (Nikon). The preparation, kept at $32^{\circ} \mathrm{C}$ via a cage incubator (Okolab), was continuously perfused with oxygenated aCSF at a flow rate of $1.25 \mathrm{ml} / \mathrm{min}$. Images were acquired on a Zyla v5.5 sCMOS camera (Andor) at $0.5 \mathrm{~Hz}$. frame-rate, through an $10 \times$ (NA 0.45) or $20 \times$ (NA 0.75) objective, combining $488 \mathrm{~nm}$ laser excitation with 500-550 nm emission collection. A single focal plane (zaxis) was maintained using the Nikon Perfect Focus System. Minor tissue drift in the $x-y$ axis was corrected using NIS Elements. Imaging displaying major drift were excluded from final analysis. Changes in Kiss $1^{\text {ARH }}$ neuron $\mathrm{Ca}^{2+}$ levels were measured in regions of interest (ROIs) comprising the GCaMP6s-positive cell bodies. In all recordings, background fluorescence measured in an $\mathrm{ROI}$ drawn on nearby tissue was subtracted from every $\mathrm{ROI} .\left[\mathrm{Ca}^{2+}\right]_{i}$ variations after drug applications were assessed as changes in fluorescence signals over baseline $\left(\Delta F / F_{0}\right)$. To normalize the fluorescence value of each cell, we first separated experimental trials into two parts: a baseline period ( $2 \mathrm{~min}$ ) corresponding to all the frames recorded before addition of drugs, and a stimulus period, after the onset of the drug (such as bath-applied senktide) application and lasting several minutes. Next, for each ROI we calculated $\Delta F / F_{0}$ for each frame $(t)$, where $\Delta F / F_{0}$ equals $\left(F_{(t)}-F_{0}\right) / F_{0}$, and $F_{0}$ was the mean fluorescence value for that $\mathrm{ROI}$ for all frames in the baseline period for that trial. The area under the curve (AUC) was calculated over the time periods of 2 min before and $18 \mathrm{~min}$ after drug application. Maximal peak reached after drug application was also measured and used in quantitative analysis. Data were averaged across all Kiss $1^{\mathrm{ARH}}$ neurons in a slice (two slices per animal), which were used as the statistical unit over a minimum of 3 animals per condition.

\section{Single cell RT-PCR (scRT-PCR)}

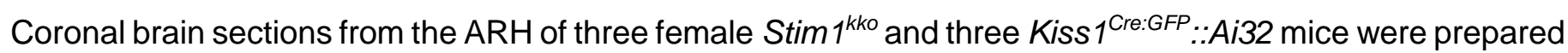
for electrophysiology and scRT-PCR. The 3-4 slices obtained were divided between electrophysiological recording experiments and single cell harvesting. Single cell dispersion and harvesting was performed as described previously with some modifcations as described below (Bosch et al., 2013; Zhang et al., 2013b). Briefly, the ARH was dissected and digested in papain ( $7 \mathrm{mg} / \mathrm{ml}$ in aCSF, Sigma-Aldrich). Gentle trituration using varying sizes of flame polished Pasteur pipets were used to disperse the cells and then they were plated onto a glass bottom dish. A constant flow of oxygenated aCSF ( $\mathrm{NaCl}, 125 \mathrm{mM} ; \mathrm{KCl}, 5 \mathrm{mM} ; \mathrm{NaH}_{2} \mathrm{PO}_{4}, 1.44 \mathrm{mM}$; Hepes, 
$2165 \mathrm{mM}$; D-glucose, $10 \mathrm{mM}$; $\mathrm{NaHCO}_{3}, 26 \mathrm{mM}$; $\mathrm{MgSO}_{4} \cdot 7 \mathrm{H}_{2} \mathrm{O}, 2 \mathrm{mM} ; \mathrm{CaCl}_{2}, 2 \mathrm{mM}$ ) was applied to the dish to keep the cells healthy and to clear debris. Fluorescent neurons were visualized under an inverted microscope. The Xenoworks Microinjection system (Sutter Instruments) was used to manipulate a $10 \mu \mathrm{m}$ tip size glass capillary tube to approach single neurons, apply gently suction and harvest single cells or pools of 10 cells into a siliconized tube containing a solution of $1 \mathrm{X}$ Invitrogen Superscript III Buffer (LifeTech), 15U of RNasin (Promega), $10 \mathrm{mM}$ of dithiothreitol (DTT) and diethylpyrocarbonate (DEPC)-treated water in a total of $5 \mu$ l for single cells or $8 \mu \mathrm{l}$ for pools of 10 cells. Corresponding controls were collected at the same time including single neurons (processed without reverse transcriptase) and aCSF from the surrounding area. Hypothalamic tissue RNA was also processed with and without reverse transcriptase. First strand cDNA synthesis was performed on single cells, pools of cells and controls in a $20 \mu \mathrm{l}$ (single cells) or $25 \mu \mathrm{l}$ (10 cell pools) volume containing a final concentration of $1 X$ Invitrogen Superscript III Buffer, $30 \mathrm{U}$ of RNasin, 15 mM DTT, 10 mM dNTP, 100 ng Random Primers (Promega), 400 ng Anchored Oligo (dT) 20 Primer (Invitrogen), 100 U Superscript III Reverse Transcriptase (Life Tech) and DEPC-treated water according to manufactures protocol and stored at $-20^{\circ} \mathrm{C}$. Clone Manager software (Sci Ed Software) was used to design primers that cross at least one intron-exon boundary. In order to confirm that STIM1 was knocked out, STIM1 primers were designed to include part of exon 2 (see Table 1). Single cell PCR conditions were optimized for primer concentration, magnesium concentration and annealing temperature. Standard curves were generated using hypothalamic cDNA with dilutions from $1: 50$ to $1: 12,800$ for primers used for qPCR to determine the efficiency $\left(E=10^{(-1 / m)}-1 ;\right.$ table 1$)$. Primer pairs with efficiencies of $90-100 \%$ permit the use of the comparative $\Delta \Delta C T$ method for analysis (Livak and Schmittgen, 2001; Pfaffl, 2001).

PCR for Kiss1, Stim1, Trpc4 and Trpc5 mRNAs was performed on $3 \mu$ of cDNA from single cells in a $30 \mu l$ reaction volume containing $1 \mathrm{X}$ GoTaq Flexi buffer (Promega), $2 \mathrm{mM} \mathrm{MgCl} 2,10 \mathrm{mM}$ dNTP, $0.33 \mu \mathrm{M}$ forward and reverse primers, 2 U GoTaq Flexi Polymerase (Promega) and 0.22 $\mu \mathrm{g}$ TaqStart Antibody (Clontech). 45-50 cycles of amplification were performed on a Bio-Rad C1000 thermocycler and the resulting product visualized with ethidium bromide on a $2 \%$ agarose gel. 
bioRxiv preprint doi: https://doi.org/10.1101/2020.09.09.289017; this version posted April 1, 2021. The copyright holder for this preprint (which was not certified by peer review) is the author/funder, who has granted bioRxiv a license to display the preprint in perpetuity. It is made available under aCC-BY 4.0 International license.

Quantitative PCR (qPCR) was performed on 3-4 $\mu$ l of cDNA from pools of 5-10 cells (3-4 pools/animal) in duplicate for the target genes (Stim1, Stim2, Trpc4 and Trpc5) and $2 \mu \mathrm{l}$ in duplicate for the reference gene (Gapdh) in a $20 \mu$ reaction volume containing 1X Power SYBR Green PCR Master Mix (Applied Biosystems) and $0.5 \mu \mathrm{M}$ forward and reverse primers. Forty cycles of amplification were run on a Quant Studio 7 Flex RealTime PCR System (Applied Biosystems) and the resulting data was analyzed using the comparative $\triangle \Delta C T$ method (Livak and Schmittgen, 2001; Pfaffl, 2001). The relative linear quantity was determined with the $2^{-\Delta \Delta C T}$ equation (Bosch et al., 2013). The mean of all of the $\Delta C T$ values $(\Delta C T=C T$ of the target gene $-C T$ of the reference gene) from the controls was used as the calibrator and the data is expressed as fold change in gene expression.

\section{Drugs}

A standard artificial cerebrospinal fluid was used (Qiu et al., 2011). All drugs were purchased from Tocris Bioscience (Minneapolis, MN) unless otherwise specified. Tetrodotoxin (TTX) was purchased from Alomone Labs (Jerusalem, Israel) (1 mM) and dissolved in $\mathrm{H}_{2} \mathrm{O}$. Thapsigargin ( $\left.\mathrm{Tg}, 2 \mathrm{mM}\right)$, TacR3 agonist senktide (1 mM) and TRPC4/5 antagonist, HC 070 (from MedChemExpress, $10 \mathrm{mM}$ ) were prepared in dimethylsulfoxide (DMSO). Aliquots of the stock solutions were stored as appropriate until needed.

\section{Data analysis}

For qPCR four Kiss 1 neuronal pools (10 cells/pool) from each animal were run in duplicate for the mRNAs that encode for STIM1, STIM2 and GAPDH and the mean value of each gene from each animal ( $n=3$ animals) was used for statistical analysis. Data are expressed as mean \pm SEM and were analyzed using an unpaired student's t-test. In addition, Kiss1 neuronal pools (5-10 cells/pool) were used to determine the expression of Trpc4 and Trpc5 in these neurons. For scRT-PCR the number of Kiss1-positive cells harvested from Kiss 1 Cre:GFP

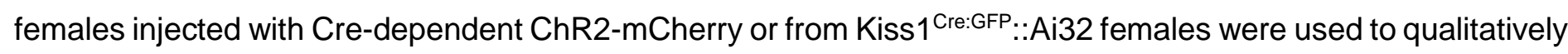
assess the number of Kiss1 neurons with Stim1, Stim2, Trpc4, Trpc5 and percent expression.

Comparisons between different treatments were performed using a repeated measures, two-way or one-way 
ANOVA analysis with the post hoc Bonferroni's test. Differences were considered statistically significant if $p<$

0.05. All data are expressed as mean \pm SEM.

\section{Results}

Validation of conditional deletion of Stim1 in Kiss 1 neurons

STIM1 is involved in the regulation of neuronal firing in cerebellar Purkinje neurons (Hartmann et al., 2014; Ryu et al., 2017), dopaminergic neurons (Sun et al., 2017) and hypothalamic arcuate POMC neurons (Qiu et al., 2018b). Initially to see if STIM1 regulates Kiss $1^{\mathrm{ARH}}$ neuronal excitability, we measured the mRNA expression of Stim1 and its close homolog Stim2 in manually harvested Kiss1 ${ }^{\text {ARH }}$ neurons by quantitative real-time PCR (Figure 1A). Based on the qPCR, mRNA levels of Stim1 were greater than those of Stim2 in Kiss $1{ }^{\mathrm{ARH}}$ neurons (Figure 1A1). Likewise, in cerebellar Purkinje neurons, Stim1 is also much more abundant than Stim2 (Hartmann et al., 2014), while in hippocampal (Berna-Erro et al., 2009) and cortical neurons (Gruszczynska-Biegala et al., 2011) Stim2 expression levels exceed those of Stim1. A qualitative, unbiased sampling of Kiss $1^{\mathrm{ARH}}$ neurons $(n=60)$ from ovariectomized Kiss $1^{\text {Cre }}$ females $(n=3)$ revealed that Stim1 mRNA was expressed in $81.7 \pm 7.6$ percent and Stim2 mRNA was detected in $81.2 \pm 2.7$ percent of Kiss $1^{\mathrm{ARH}}$ neurons with 70 percent of neurons expressing both Stim1 and Stim2.

To elucidate the functional role of STIM1 in Kiss1 neurons, we generated mice that lack STIM1 selectively in Kiss 1 neurons (Stim ${ }^{k k o}$, detailed in Methods). We confirmed the Stim1 deletion in Stim ${ }^{k k o}$ mice using single cell quantitative PCR of pools of harvested Kiss $1^{\mathrm{ARH}}$ neurons ( $\mathrm{n}=3$ animals) (Figure 1A2). Consistent with the scRTPCR results (Figure 1B), Stim1 mRNA was undetectable in Stim ${ }^{k k o}$ neurons (Figure 1A2), whereas there was no reduction in Stim2 mRNA expression (Figure 1A3). In contrast, Stim1 mRNA was still expressed in the majority of adjacent nonfluorescent neurons obtained from both Stim $1^{\text {kko }}$ and Kiss $1^{\text {Cre }}$ mice. 
SOCE constitutes an important source of calcium entry and signaling in neurons. Depletion of ER $\mathrm{Ca}^{2+}$ stores causes the ER $\mathrm{Ca}^{2+}$ sensor STIM proteins (STIM1 and STIM2) to interact with and activate cell surface $\mathrm{Ca}^{2+}$ release-activated $\mathrm{Ca}^{2+}$ (CRAC) channels, thereby resulting in a second wave of cytoplasmic $\mathrm{Ca}^{2+}$ rise (Moccia et al., 2015). Genetic suppression of Stim1 in neural progenitor cells results in abrogation of this second wave of calcium rise that constitutes SOCE (Somasundaram et al., 2014). We asked whether deletion of Stim1 in Kiss $1^{\text {ARH }}$ neurons $\left(S t i m 1^{k k o}\right.$ ) attenuates neuronal SOCE. Kiss $1^{\text {Cre }}$ and Stim $1^{\text {kko }}$ mice received bilateral ARH injections of GCaMP6 viral vector (Figure 1C1, C2), and the Kiss $1^{\text {ARH }}$ or Stim $1^{\text {kko }}$ neurons with GCaMP6s in slices were imaged using spinning disk confocal microscopy (Figure 2-video supplement 1). ER $\mathrm{Ca}^{2+}$ stores were released by treatment with $2 \mu \mathrm{M}$ thapsigargin $(\mathrm{Tg})$, a blocker of the SERCA (sarcoplasmic/endoplasmic reticulum $\mathrm{Ca}^{2+}$ ATPase) pump. As expected, $\mathrm{Tg}$ treatment of neurons bathed in $\mathrm{Ca}^{2+}$-free aCSF generated an initial wave of cytoplasmic $\mathrm{Ca}^{2+}$ release $\left(\left[\mathrm{Ca}^{2+}\right]_{i}\right)$ as measured by an increase in GCaMP6s activity both in control and Stim1-deleted neurons (Figure 1D, E and F). As long as neurons were kept in $\mathrm{Ca}^{2+}$ - free aCSF, the ER stores remained empty, a situation that was presumably sensed by the $\mathrm{Ca}^{2+}$ sensor STIMs. Upon switching to a normal aCSF containing $2 \mathrm{mM} \mathrm{Ca}^{2+}$, an immediate SOCE response was observed as a second wave of cytoplasmic $\mathrm{Ca}^{2+}$ rise. Consistent with a role for STIM1 regulation, we observed an attenuation of SOCE in Stim ${ }^{\text {kko }}$ neurons (Figure 1D, E, F and G: $\Delta \mathrm{F} / \mathrm{F}_{0}{ }^{\star} 100=1274.5 \pm 49.4, \mathrm{n}=4$, Kiss $1^{\mathrm{ARH}}$ group versus $389.0 \pm 86.1$, $\mathrm{n}=4$, Stim $1^{\mathrm{k} \mathrm{ko}}$ group, which was measured from the 15 minute time point to the peak, unpaired t-test, $t_{(6)}=8.921$, $\left.p=0.0001,{ }^{* * *} p<0.005\right)$, indicating that STIM1 plays a major role in SOCE after Tg-induced ER $\mathrm{Ca}^{2+}$ depletion in Kiss $1^{\text {ARH }}$ neurons as has been shown in other CNS neurons (Guner et al., 2017; Pavez et al., 2019).

\section{TacR3 -induced increase in $\left[\mathrm{Ca}^{2+}\right]_{i}$ is augmented by deletion of Stim 1}

TacR3 classically couples to a Gaq protein-calcium signaling and excites Kiss $1^{\text {ARH }}$ neurons (de Croft et al., 2013; Ruka et al., 2013; Qiu et al., 2016). Calcium is of critical importance to neurons as it participates in the transmission of depolarizing signals and contributes to synaptic activity (Brini et al., 2014). Therefore, we tested whether STIM1 can modulate TacR3-mediated calcium responses. We first measured the effects of the TacR3, which is Gq-coupled, agonist senktide on GCaMP6s-expressing Kiss $1^{\text {ARH }}$ neurons in arcuate slices from Kiss $1^{\text {Cre }}$ mice; senktide $(1 \mu \mathrm{M})$ rapidly induced an increase in $\left[\mathrm{Ca}^{2+}\right]_{i}$ (Figures $\left.2 A, C\right)$. Next, we investigated if STIM1 
contributes to intracellular rise in $\left[\mathrm{Ca}^{2+}\right]_{i}$ after senktide activation. Indeed, deletion of Stim1 significantly augmented the peak TacR3-mediated response by $\sim$ three-fold $\left(\Delta \mathrm{F} / \mathrm{F}_{0}{ }^{*} 100=244.0 \pm 27.7, \mathrm{n}=7\right.$ slices, Kiss $1^{\mathrm{ARH}}$ group versus $622.1 \pm 133.2, n=6$ slices), Stim $1^{k k o}$ group; two-way ANOVA: main effect of treatment $\left(F_{(1,11)}=\right.$ $5.265, p=0.0424)$, main effect of time $\left(\mathrm{F}_{(19,209)}=42.69, \mathrm{p}<0.0001\right)$ and interaction $\left(\mathrm{F}_{(19,209)}=6.486, p<0.0001\right)$; post hoc Bonferroni test, ${ }^{* \star *} p<0.001 ;{ }^{* *} p<0.01 ;{ }^{*} p<0.05$ ). (Figures $2 \mathbf{B}, \boldsymbol{C}$ ). Likewise, the area under the curve was significantly increased in the Stim $1^{\text {kko }}$ group by four-fold (Kiss $1^{\text {cre: }} 954.8 \pm 200.4, \mathrm{n}=7$ versus Kiss $1^{\text {kko: }}$ $3746.0 \pm 1227.0, \mathrm{n}=6)$ (Figure 2D).

\section{Deletion of STIM1 enhances slow EPSP in Kiss $1^{A R H}$ neurons}

Kiss $1^{A R H}$ neurons are the chief component of the GnRH pulse generator circuit (Navarro et al., 2009; Lehman et al., 2010; Navarro et al., 2011; Okamura et al., 2013), such that they synchronize their activity to trigger the release of peptides to drive pulsatile release of GnRH (Qiu et al., 2016; Clarkson et al., 2017). To investigate if STIM1 modulates the activity of Kiss $1^{\mathrm{ARH}}$ neurons, we bilaterally injected AAV1-Ef1a-DIO-ChR2:mCherry into the arcuate nucleus of Kiss $1^{\mathrm{Cre}}$ and Stim $1^{\text {kko }}$ mice. To verify that Trpc5 mRNAs is co-localized in these Kiss $1^{\mathrm{ARH}}$ neurons, we harvested 50 Kiss $1^{\text {ARH }}$ neurons from 2 females and did scRT-PCR for Trpc5 and Trpc4 expression. The single-cell analysis revealed that Trpc5 transcript was detectable in $82 \%$ of Kiss $1^{\text {ARH }}$ neurons, but Trpc4 mRNA was not detected in Kiss $1^{\mathrm{ARH}}$ neurons (Figure 3A). Moreover, quantitative single cell PCR documented that $\operatorname{Trpc5}$ but not Trpc4 mRNA was expressed in Kiss $1^{\mathrm{ARH}}$ neurons (Figure 3B). With whole-cell recording we verified the expression of TRPC5 channels by documenting the senktide - induced typical double-rectifying I/V plot characteristic of the activation of TRPC5 channels (Figure 3C) as we previously reported (Kelly et al., 2018). Initially, whole-cell patch recording in Kiss $1^{\mathrm{ARH}}$ neurons from ovariectomized Kiss1 or Stim $1^{\text {kko }}$ female mice revealed that there was no difference in the resting membrane potential (RMP: Kiss1: $-66.0 \pm 1.7 \mathrm{mV}, \mathrm{n}=38$ versus Stim 1kko: $-68.2 \pm 0.9 \mathrm{mV}, \mathrm{n}=58)$ or membrane capacitance $\left(\mathrm{C}_{\mathrm{m}}\right.$ : Kiss1: $25.0 \pm 1.0 \mathrm{pF}, \mathrm{n}=38$ versus Stim $1^{\text {kko: }}: 27.3 \pm 0.9 \mathrm{pF}, \mathrm{n}=58$ ). However, there was a significant difference in the membrane input resistance (Rin: Kiss1: $524.2 \pm 42.4 \Omega, \mathrm{n}=38$, versus Stim 1 ${ }^{\mathrm{kko}}: 417.3 \pm 26.9 \Omega, \mathrm{n}=58$, unpaired two-tailed $t$ test, $\mathrm{t}_{(94)}=$ 2.242, $p=0.0273$ ), which has also been reported with Stim 1 knockout in cerebellar Purkinje neurons (Ryu et al., 2017). Kiss $1^{\mathrm{ARH}}$ neurons expressing ChR2-mCherry in slices were photostimulated at $20 \mathrm{~Hz}$ for $10 \mathrm{~s}$ (Figure 
350

351

352

353

354

355

356

357

358

359

360

361

362

363

364

365

366

367

368

369

370

371

372

373

374

375

376

3-video supplement 1) to generate slow EPSPs as previously described (Qiu et al., 2016). As we had hypothesized, deletion of Stim1 augmented the slow EPSP induced by high-frequency optogenetic stimulation

(Figure 3D-F). Also in the presence of TTX to block voltage-gated $\mathrm{Na}^{+}$channels, we observed that senktide induced larger inward currents in Kiss $1^{\mathrm{ARH}}$ neurons from Stim $1^{\text {kko }}$ mice versus Kiss $1^{\mathrm{Cre}}$ mice (Figure $4 \boldsymbol{A}-\boldsymbol{C}$ ). Although the senktide-induced cation current was significantly increased by Stim 1 deletion, the I/V plots revealed that the reversal potential for the current was not different between Kiss $1^{\text {ARH }}$ neurons recorded from Stim $1^{\text {kko }}$ mice or Kiss $1^{\text {Cre }}$ mice (Kiss1: $-10.5 \pm 2.1 \mathrm{mV}, \mathrm{n}=4$, vs Stim $1^{\mathrm{kko}}$ : $-9.8 \pm 2.2 \mathrm{mV}, \mathrm{n}=4$, unpaired two-tailed $t$ test, $\left.\mathrm{t}_{(6)}=0.2503, \mathrm{p}=0.8107\right)($ Figure $4 \boldsymbol{D}-\boldsymbol{F})$. These results indicate that STIM1 expression governs the activity of TRPC5 channels, which contribute to the synchronous activity of Kiss $1^{\mathrm{ARH}}$ neurons.

NKB agonist activates TRPC5 channels in Kiss $1^{\text {ARH }}$ neurons from Kiss $1^{\text {Cre }}$ and Stim $1^{\text {kko }}$ mice

Based on our previous findings that TPRC 5 channel protein is expressed in Kiss $1^{\mathrm{ARH}}$ neurons and is activated by the NKB agonist senktide (Qiu et al., 2011; Kelly et al., 2018), we investigated the contribution of TRPC5 channels to generating the slow EPSP. We used a ratio method in which a slow EPSP was generated by optogenetic stimulation $(20 \mathrm{~Hz}, 10 \mathrm{~s})$ of Kiss $1^{\text {Cre }}$.ChR2 neurons and then stimulated again 10 min later after drug exposure (Qiu et al., 2016). For the Kiss $1^{A R H}$ neurons from ovariectomized female Kiss 1:Ai32 mice, the RMP, $\mathrm{C}_{\mathrm{m}}$ and $\mathrm{R}_{\text {in }}$ were $-72.7 \pm 0.8 \mathrm{mV}, 22.4 \pm 0.7 \mathrm{pF}$ and $458.6 \pm 23.3 \Omega, \mathrm{n}=50$, respectively. Using this protocol, we found that the slow EPSP was inhibited by perfusing the TRPC4/5 channel blocker HC 070 (100 nM) (Just et al., 2018) for 5 minutes, and the ratio was significantly decreased from 60 to 30 percent (Figure 5A-C). Since Trpc4 mRNA is not expressed in Kiss $1^{\text {ARH }}$ neurons (Figure 3A, B), we would argue that TRPC5 channels mediate the slow EPSP in these neurons. To elucidate the TRPC5 channel contribution to the postsynaptic activity of Kiss $1^{\text {ARH }}$ neurons from Stim $1^{\text {kko }}$ mice, we perfused TTX to block fast sodium channels and found that HC 070 significantly suppressed the senktide-induced inward current (Figure 5D, E and F).

Stim1 deletion in Kiss ${ }^{A R H}$ neurons has minimal effects on estrous cycle

Stim $1^{k k o}$ mice on the C57BL/ 6 background were viable at the expected Mendelian ratio and did not show any difference in the time to vaginal opening (Stim $1{ }^{\mathrm{kko}}$ mice: postnatal day $30.2 \pm 0.8, n=21$ versus Kiss $1^{\text {Cre }}$ 
mice: postnatal day $29.1 \pm 0.8, \mathrm{n}=19$, Unpaired $t$ test, $\left.t_{(38)}=1.003, p=0.3222\right)$. However, since kisspeptin neurons are responsible for the maintenance of the reproductive cycle (Seminara et al., 2003; d'Anglemont de Tassigny et al., 2007; Mayer et al., 2010), and Stim1 deletion facilitated the synchronous firing of Kiss $1^{\text {ARH }}$ neurons, we measured the effects of Stim1 deletion in Kiss1 neurons on the estrous cycle. We monitored the estrous cycle of Stim $1^{k k o}$ and $K i s s 1^{\text {Cre }}$ female mice with vaginal lavage for two weeks before ovariectomy for the metabolic studies (see below). Stim $1^{\text {kko }}$ female mice exhibited prolonged estrous cycles versus the Kiss $1^{\mathrm{Cre}}$ females (Figure 6A,B,C versus $6 D, E, F$ ) with a slight prolongation of estrous days (Figure $6 H$ ). Although more in depth analysis is warranted (i.e., measurement of pulsatile $\mathrm{LH}$ ), the results were not unexpected since augmented synchronous activity of Kiss $1^{\mathrm{ARH}}$ neurons, as we documented at the cellular level, should still drive luteinizing hormone (LH) pulses in these female mice (Qiu et al., 2016; Clarkson et al., 2017).

Stim1 deletion in Kiss $1^{A R H}$ neurons protects ovariectomized females against diet-induced obesity

Subsequently, the same two cohorts of female mice, Stim $1^{\text {kko }}(n=10)$ and the littermate control Kiss $1^{\text {Cre }}$ $(n=10)$ mice, were ovariectomized at around 3 months of age and put on a high fat diet for eight weeks (see Methods). Over this time period, there was significantly less gain in body weight in the Stim $1^{k k o}$ versus the Kiss $1^{\text {Cre }}$ mice (Figure $7 A, B$ ). Moreover, the average fat mass of Stim ${ }^{k k o}$ mice was significantly lighter than that of Kiss $1^{\text {Cre }}$ controls by week 6 (Stim $1^{\text {kko }}$ versus Kiss $1^{\text {Cre }}$ mice fat mass: $7.6 \pm 0.9 \mathrm{~g}, \mathrm{n}=10$ versus $11.4 \pm 1.1 \mathrm{~g}$, $\mathrm{n}=10$ ) (Figure 7C). The lean mass of Stim $1^{\text {kko }}$ mice was also significantly less versus the Kiss $1^{\text {Cre }}$ mice $\left(\right.$ Stim $1^{k k o}$ versus the Kiss $1^{\text {Cre }}$ mice lean mass: $16.9 \pm 0.4 \mathrm{~g}, \mathrm{n}=10$ versus $18.9 \pm 0.4 \mathrm{~g}, \mathrm{n}=10$ ) (Figure $7 D$ ). After 6 weeks, both Stim ${ }^{k k o}$ and Kiss $1^{\text {Cre }}$ controls were assessed for glucose tolerance using an i.p. glucose tolerance test (see Methods). Both Stim ${ }^{k k o}$ and Kiss $1^{\text {Cre }}$ females started at relatively the same blood glucose levels after an overnight fast (Figure 7E, time 0), suggesting similar whole-body homeostatic conditions after fasting. However, Stim $1^{\text {koo }}$ female mice had significantly lower glucose levels after i.p. glucose compared to Kiss ${ }^{\text {Cre }}$ females, indicating that Stim $1^{\text {kko }}$ females were more glucose tolerant compared to Kiss $1^{\mathrm{Cre}}$ controls. Stim ${ }^{k k o}$ females had a significantly higher glucose clearance rate than controls based on the integrated area under the curve (Stim ${ }^{k k o}$ versus the Kiss $1^{\text {Cre }}$ controls AUC: $20,232 \pm 868 \mathrm{mg} / \mathrm{dL} \times \min , \mathrm{n}=6$ versus $22,622 \pm 624 \mathrm{mg} / \mathrm{dL} \times \mathrm{min}, \mathrm{n}=6$ ). Finally, when both groups were euthanized after eight weeks on HFD and the tissues harvested, both the 
404 intrascapular brown adipose tissue (iBAT) and perigonadal adipose tissue (GAT) were dissected from each

405 mouse and weighed. Both iBAT and GAT masses were significantly lighter in the Stim $1^{\text {kko }}$ versus the Kiss $1^{\text {Cre }}$ 406 females (Stim $1^{k k o}$ versus the Kiss $1^{\text {Cre }}$ iBAT: $73.3 \pm 6.0 \mathrm{mg}, \mathrm{n}=10$ versus $97.3 \pm 9.6 \mathrm{mg}, \mathrm{n}=10$; Stim $1^{\text {kko }}$ versus

the Kiss ${ }^{\text {Cre }}$ GAT: $1.5 \pm 0.2 \mathrm{~g}, \mathrm{n}=10$ versus $2.3 \pm 0.2 \mathrm{~g}, \mathrm{n}=10$ ) (Figures $7 \boldsymbol{F}, \mathbf{G}$ ). Overall, these results suggest that conditional deletion of Stim1 in Kiss $1^{\mathrm{ARH}}$ neurons affords some protection against diet-induced obesity. However, we cannot overlook the possibility that deletion of Stim1 in Kiss1-expressing hepatocytes might contribute to this metabolic phenotype (Song et al., 2014).

\section{Discussion}

For the first time, we show that conditional knockout of Stim1 significantly reduces store-operated $\mathrm{Ca}^{2+}$ entry (SOCE) in Kiss $1^{\mathrm{ARH}}$ neurons following thapsigargin-mediated depletion of $\mathrm{Ca}^{2+}$ stores. Based on single cell qPCR analysis, Stim1 mRNA was expressed at approximately two-fold higher levels than Stim2 in Kiss $1^{\text {ARH }}$ neurons, and deletion of Stim1 did not alter expression of Stim2 in Kiss $1^{\mathrm{ARH}}$ neurons-i.e., there was no developmental compensation. Selective deletion of Stim1 in Kiss $1^{\text {ARH }}$ neurons augmented the TacR3-mediated increase in $\left[\mathrm{Ca}^{2+}\right]_{i}$ and synchronous activity of Kiss $1{ }^{\mathrm{ARH}}$ neurons by almost 4-fold. Whole-cell recording revealed that the slow EPSP induced by high-frequency optogenetic stimulation of Kiss $1^{\mathrm{ARH}}$ :ChR2 neurons was significantly enhanced by Stim1 deletion. This augmentation of the slow EPSP was mediated by TacR3 coupling to TRPC 5 channel activation since the senktide-induced inward current was equally enhanced. Moreover, the inward current exhibited the signature double rectifying I/V plot of TRPC 5 channels and was antagonized by the TRPC 4/5 channel blocker HC070. The enhanced TacR3 signaling in Stim $1^{k k o}$ female mice afforded some protection against diet-induced obesity and glucose intolerance.

Mammalian TRPC channels can be activated by G protein-coupled receptors and receptor tyrosine kinases (Clapham, 2003; Ambudkar and Ong, 2007) and are one of the major targets for group I metabotropic glutamate receptor (mGluR1) signaling in CNS neurons (Tozzi et al., 2003; Bengtson et al., 2004; Faber et al., 2006; Berg et al., 2007). In substantia nigra dopamine neurons TRPC 5 channels are highly expressed, and mGluR1 agonists induce a current that exhibits a double-rectifying current-voltage plot (Tozzi et al., 2003) similar to the 
431 effects of the NKB agonist senktide in Kiss $1^{\text {ARH }}$ neurons (Figure 3). Both mGluR1 and TacR3 are Gq-coupled

to phospholipase $\mathrm{C}$ (PLC) activation which leads to hydrolysis of phosphatidylinositol 4,5-bisphosphate $\left(\mathrm{PIP}_{2}\right)$ to diacylglycerol (DAG) and inositol 1,4,5 triphosphate $\left(\mathrm{IP}_{3}\right)$. TRPC channels are minimally $\mathrm{Ca}^{2+}$ selective, but can associate with Orai calcium channels to form calcium release-activated calcium channels (Birnbaumer, 2009). A unique feature of TRPC 5 (and TRPC 4) channels is that they are potentiated by lanthanum ( La $\left.^{3+}\right)(\mathrm{Clapham}$ et al., 2005), which we have exploited to characterize TPRC 5 signaling in POMC neurons (Qiu et al., 2010; Qiu et al., 2014).

Both leptin and insulin excite/depolarize Kiss $1^{\mathrm{ARH}}$ and proopiomelanocortin (POMC) neurons through activation of TRPC 5 channels (Qiu et al., 2010; Qiu et al., 2011; Qiu et al., 2014; Kelly et al., 2018). More recently, we documented a critical role of STIM1 in the insulin signaling cascade in POMC neurons (Qiu et al., 2018b). Stim1 mRNA is highly expressed in POMC (Qiu et al., 2018b) and Kiss ${ }^{\mathrm{ARH}}$ neurons (Figure 1), and E2 downregulates Stim1 mRNA expression in microdissected arcuate nuclei that encompasses these two populations of neurons. Downregulation of Stim1 is critical for maintaining insulin excitability in POMC neurons with diet-induced obesity (Qiu et al., 2018b). In ovariectomized females that are relatively refractory to insulin excitation, pharmacological blockade of the SOCE complex quickly increases the insulin-mediated excitation of POMC neurons (i.e., activation of the TRPC 5 mediated inward current), which supports the concept that TRPC 5 channels play a role both in SOCE and receptor operated calcium entry (Birnbaumer, 2009; Salido et al., 2011).

Therefore, selective deletion of Stim 1 in Kiss 1 neurons should ensure that TRPC 5 channels function as receptoroperated channels to couple TacR3's and transmit the excitatory effects of NKB to induce synchronous firing of Kiss $1^{\mathrm{ARH}}$ neurons as demonstrated in the present findings.

Downregulating STIM1 inhibits SOCE, attenuates $\mathrm{Ca}^{2+}$ influx into the ER and elevates intracellular $\mathrm{Ca}^{2+}$ levels, which could also contribute to activation of TRPC5 channels in Kiss $1^{\mathrm{ARH}}$ neurons (Blair et al., 2009). Indeed, we have found that $\mathrm{Ca}^{2+}$ greatly potentiates the leptin-induced TRPC 5 current in POMC neurons (Qiu et al., 2010). In cortical neurons and heterologous cells expressing Cav1.2(L-type calcium) channels and Stim1, inhibition of STIM1 augments $\mathrm{Ca}^{2+}$ influx through L-type calcium channels (Park et al., 2010; Wang et al., 2010). 
Calcium sensing by STIM1 is also involved in the control of L-type $\mathrm{Ca}^{2+}$ channel activity in the hippocampal pyramidal neurons such that glutamate-mediated depolarization activates L-type calcium channels, and releases $\mathrm{Ca}^{2+}$ from ER stores that activates STIM1 and drives aggregation of the L-type calcium channels to inhibit their activity (Dittmer et al., 2017). Quite possibly in Kiss1 $1^{\text {ARH }}$ neurons and Purkinje cells (Ryu et al., 2017) deletion of Stim 1 allows the "dis-aggregation" of TPRC 5 channels, which is reflected in the significant decrease in $R_{\text {in }}$ in both cell types with deletion. Furthermore, knocking down STIM1 in cardiomyocyte-derived (HL-1) cells increases the peak amplitude and current density of T-type calcium channels and shifts the activation curve toward more negative membrane potentials (Nguyen et al., 2013). Biotinylation assays reveal that knocking down Stim1 increases T-type calcium channel surface expression, and co-immunoprecipitation assays suggest that STIM1 directly regulates T-type channel activity (Nguyen et al., 2013). Thus, STIM1 appears to be a negative regulator of voltage-gated calcium channel activity. On the other hand, estradiol treatment in ovariectomized females upregulates Cav3.1 channel expression by 3 -fold and whole cell currents by 10 -fold in Kiss ${ }^{\text {ARH }}$ neurons, which greatly enhances the excitability and contributes to the synchronous firing of Kiss $1^{\mathrm{ARH}}$ neurons (Qiu et al., 2018a). The T-type calcium channel Cav3.1 underlies burst firing in rostral hypothalamic kisspeptin neurons (Zhang et al., 2013b) and facilitates TRPC 4 channel activation in GnRH neurons (Zhang et al., 2008; Zhang et al., 2013a). Cav3.1 channels may also facilitate TRPC5 channel opening in Kiss $1^{\text {ARH }}$ neurons (Figure 8), but this remains to be determined.

Presumably with conditional knockout, Stim1 was deleted in all cells expressing kisspeptin, which includes arcuate, anteroventral periventricular preoptic (AVPV) and amygdala kisspeptin neurons, and non-neural kisspeptin cells in the gonads, pancreas and liver (Dudek et al., 2019). Currently, we found that the deletion of Stim1 in kisspeptin neurons had a minor effect on the estrous cycle. Stim $1^{\text {kko }}$ mice exhibited more estrous-type vaginal cytology, which may be indicative of higher levels of circulating estrogens due to increased synchronous firing of kisspeptin neurons and excitatory drive to GnRH neurons (Qiu et al., 2016; Clarkson et al., 2017). It is important to note that synchronous firing of "pulse generator" Kiss $1^{\mathrm{ARH}}$ neurons is a failsafe system for maintaining gonadotropin pulses and folliculogenesis in female rodents (Nagae et al., 2021). 
Because of the well-documented anorexigenic actions of E2 on POMC and Agouti-related peptide (AgRP) neurons controlling energy homeostasis (Qiu et al., 2006; Roepke et al., 2010; Clegg, 2012; Kelly and Rønnekleiv, 2012; Smith et al., 2013), we ovariectomized the females before feeding them a high fat diet. After 7 weeks on a high fat diet, Stim $1^{\text {kko }}$ females gained modestly less body weight but showed significantly less body fat and lean mass than ovariectomized Kiss $1^{\text {Cre }}$ females on a high fat diet. Most importantly, Stim ${ }^{\text {kko }}$ females exhibited improved glucose tolerance. Kiss $1^{\mathrm{ARH}}$ neurons probably mediate these protective effects via their input onto POMC and AgRP neurons. Besides the peptides Kiss $1{ }^{\mathrm{ARH}}$ neurons also co-express the vesicular glutamate transporter 2 (vGluT2) (Cravo et al., 2011), and we have documented that optogenetic stimulation of Kiss1 ${ }^{\mathrm{ARH}}$ neurons expressing channelrhodopsin releases glutamate, which is dependent on the estrogenic state of females (Qiu et al., 2018a). Although the mRNA expression of Kiss1, Tac2 and Pdyn mRNA in Kiss ${ }^{\text {ARH }}$ neurons are all down-regulated by E2 (Navarro et al., 2009; Lehman et al., 2010), Vglut2 mRNA expression is upregulated together with increased probability of glutamate release in E2 treated, ovariectoimzed females (Qiu et al., 2018a). Low frequency $(1-2 \mathrm{~Hz})$ optogenetic stimulation of Kiss $1^{\mathrm{ARH}}$ neurons evokes fast ionotropic glutamatergic EPSCs in POMC and AgRP neurons, but high frequency $(20 \mathrm{~Hz})$ optogenetic stimulation releases enough glutamate to induce a slow excitatory response in POMC neurons but a slow inhibitory response in AgRP neurons (Nestor et al., 2016; Qiu et al., 2016; Qiu et al., 2018a). Indeed, the group I mGluR agonist DHPG depolarizes POMC neurons, while group II/III mGluR agonists (DCG-IV; AMN082) hyperpolarize AgRP neurons (Qiu et al., 2018a). Group I mGluRs (mGluR1 and mGluR5) are $G_{q} / G_{11}$-coupled, while group II/III mGluRs (mGluR2 and mGluR7) are $G_{i} / G_{0}-$-coupled (Niswender and Conn, 2010). Hence, the output of Kiss $1^{\text {ARH }}$ neurons excites the anorexigenic POMC neurons and inhibits the orexigenic AgRP neurons. Therefore, Kiss $1{ }^{\mathrm{ARH}}$ neurons appear to be an integral part of an anorexigenic circuit in the hypothalamus (Qiu et al., 2018a; Rønnekleiv et al., 2019; Navarro, 2020).

Presently, there is compelling evidence that Kiss $1^{\mathrm{ARH}}$ neurons are a critical "command" neuron for coordinating energy states with reproductive functions (see (Rønnekleiv et al., 2019; Navarro, 2020) for review). We have now documented that conditional knockout of Stim1 in Kiss $1^{\mathrm{ARH}}$ neurons, which augments the NKBmediated depolarization of these neurons via TRPC 5 channels, helps protect ovariectomized, female mice from 
diet-induced obesity and glucose intolerance. In addition, in preliminary experiments we have found that insulin

treatment in vitro increases the synchronous firing (GCaMP6 activity) of Kiss1 ${ }^{\mathrm{ARH}}$ neurons, which further emphasizes its role as a "command" neuron. Clearly, Kiss $1{ }^{\mathrm{ARH}}$ neurons are part of a hypothalamic circuit for coordinating reproduction with energy balance, but additional experiments are needed to elucidate the cellular mechanisms by which steroid and metabolic hormonal signaling synergize to govern their activity.

\section{References}

Ambudkar IS, Ong HL (2007) Organization and function of TRPC channelsomes. Pflügers Archiv: European Journal of Physiology 455:187-200.

Asarian L, Geary N (2006) Modulation of appetite by gonadal steroid hormones. Philosophical Transactions of the Royal Society B: Biological Sciences 361:1251-1263.

Ayala JE, Samuel VT, Morton GJ, Obici S, Croniger CM, Shulman GI, Wasserman DH, McGuinness OP, Consortium NIHMMPC (2010) Standard operating procedures for describing and performing metabolic tests of glucose homeostasis in mice. Disease Models \& Mechanisms 3:525-534.

Bengtson CP, Tozzi A, Bernardi G, Mercuri NB (2004) Transient receptor potential-like channels mediate metabotropic glutamate receptor EPSCs in rat dopamine neurones. The Journal of Physiology 555:323330.

Berg AP, Sen N, Bayliss DA (2007) TrpC3/C7 and Slo2.1 are molecular targets for metabotropic glutamate receptor signaling in rat striatal cholinergic interneurons. The Journal of Neuroscience 27:8845-8856.

Berna-Erro A, Braun A, Kraft R, Kleinschnitz C, Schuhmann MK, Stegner D, Wultsch T, Eilers J, Meuth SG, Stoll G, Nieswandt B (2009) STIM2 Regulates Capacitive Ca ${ }^{2+}$ Entry in Neurons and Plays a Key Role in Hypoxic Neuronal Cell Death. Science Signaling 2:ra67-ra67.

Birnbaumer L (2009) The TRPC class of ion channels: a critical review of their roles in slow, sustained increases in intracellular $\mathrm{Ca}^{2+}$ concentrations. Annual Review of Pharmacology and Toxicology 49:395426.

Blair NT, Kaczmarek JS, Clapham DE (2009) Intracellular calcium strongly potentiates agonist-activated 
TRPC5 channels. The Journal of General Physiology 133:525-546.

Bosch MA, Tonsfeldt KJ, Rønnekleiv OK (2013) mRNA expression of ion channels in GnRH neurons: subtypespecific regulation by 17ß-Estradiol. Molecular and Cellular Endocrinology 367:85-97.

Brini M, Calì T, Ottolini D, Carafoli E (2014) Neuronal calcium signaling: function and dysfunction. Cellular and Molecular Life Sciences 71:2787-2814.

Castellano JM, Tena-Sempere M (2013) Metabolic regulation of kisspeptin. Advances in Experimental Medicine and Biology 784:363-383.

Castellano JM, Navarro VM, Fernández-Fernández R, Nogueiras R, Tovar S, Roa J, Vazquez MJ, Vigo E, Casanueva FF, Aguilar E, Pinilla L, Dieguez C, Tena-Sempere M (2005) Changes in hypothalamic KiSS-1 system and restoration of pubertal activation of the repoductive axis by kisspeptin in undernutrition. Endocrinology 146:3917-3925.

Clapham DE (2003) TRP channels as cellular sensors. Nature 426:517-524.

Clapham DE, Julius D, Montell C, Schultz G (2005) International Union of Pharmacology. XLIX. Nomenclature and structure-function relationships of transient receptor potential channels. Pharmacological Reviews $57: 427-450$.

Clarkson J, Han SY, Piet R, McLennan T, Kane GM, Ng J, Porteous RW, Kim JS, Colledge WH, Iremonger KJ, Herbison AE (2017) Definition of the hypothalamic GnRH pulse generator in mice. Proceedings of the National Academy of Sciences of the United States of America 114:E10216-E10223.

Clegg DJ (2012) Minireview: the year in review of estrogen regulation of metabolism. Molecular Endocrinology 26:1957-1960.

Cravo RM, Margatho LO, Osborne-Lawrence S, Donato JJ, Atkin S, Bookout AL, Rovinsky S, Frazão R, Lee CE, Gautron L, Zigman JM, Elias CF (2011) Characterization of Kiss1 neurons using transgenic mouse models. Neuroscience 173:37-56.

Czaja JA (1978) Ovarian influences on primate food intake: assessment of progesterone actions. Physiology \& Behavior 21:923-928.

d'Anglemont de Tassigny X, Fagg LA, Dixon JPC, Day K, Leitch HG, Hendrick AG, Zahn D, Franceschini I, Caraty A, Carlton MBL, Aparicio SAJR, Colledge WH (2007) Hypogonadotropic hypogonadism in mice 
bioRxiv preprint doi: https://doi.org/10.1101/2020.09.09.289017; this version posted April 1, 2021. The copyright holder for this preprint (which

was not certified by peer review) is the author/funder, who has granted bioRxiv a license to display the preprint in perpetuity. It is made available under aCC-BY 4.0 International license.

566

lacking a functional KiSS 1 gene. Proceedings of the National Academy of Sciences of the United States of America 104:10714-10719.

De Bond JA, Smith JT (2014) Kisspeptin and energy balance in reproduction. Reproduction 147:R53-63.

de Croft S, Boehm U, Herbison AE (2013) Neurokinin B activates arcuate kisspeptin neurons through multiple tachykinin receptors in the male mouse. Endocrinology 154:2750-2760.

De Roux N, Genin E, Carel J-C, Matsuda F, Chaussain J-L, Milgrom E (2003) Hypogonadotropic hypogonadism due to loss of function of the KiSS 1-derived peptide receptor GPR54. Proceedings of the National Academy of Sciences of the United States of America 100:10972-10976.

Dittmer PJ, Wild AR, Dell'Acqua ML, Sather WA (2017) STIM1 Ca ${ }^{2+}$ Sensor Control of L-type Ca ${ }^{2+}$-ChannelDependent Dendritic Spine Structural Plasticity and Nuclear Signaling. Cell Reports 19:321-334.

Dudek M, Ziarniak K, Cateau M-L, Dufourny L, Sliwowska JH (2019) Diabetes type 2 and kisspeptin: Central and peripheral sex-specific actions. Trends in Endocrinology \& Metabolism 30:833-843.

Faber ES, Sedlak P, Vidovic M, Sah P (2006) Synaptic activation of transient receptor potential channels by metabotropic glutamate receptors in the lateral amygdala. Neuroscience 137:781-794.

Fernández-Fernández R, Martini AC, Navarro VM, Castellano JM, Dieguez C, Aguilar E, Pinilla L, TenaSempere M (2006) Novel signals for the integration of energy balance and reproduction. Molecular and Cellular Endocrinology 254-255:127-132.

Fu LY, van den Pol AN (2010) Kisspeptin directly excites anorexigenic proopiomelanocortin neurons but inhibits orexigenic neuropeptide $Y$ cells by an indirect synaptic mechanism. The Journal of Neuroscience 30:10205-10219.

Gao Y, Yao T, Deng Z, Sohn J-W, Sun J, Huang Y, Kong X, Yu K-J, Wang R-T, Chen H, Guo H, Yan J, Cunningham KA, Chang Y, Liu T, Williams KW (2017) TrpC5 mediates acute leptin and serotonin effects via Pomc neurons. Cell Reports 18:583-592.

Goodman RL, Lehman MN, Smith JT, Coolen LM, de Oliveira CVR, Jafarzadehshirazi MR, Pereira A, Iqbal J, Caraty A, Ciofi P, Clarke IJ (2007) Kisspeptin neurons in the arcuate nucleus of the ewe express both dynorphin A and neurokinin B. Endocrinology 148:5752-5760. 
STIM2 in Store-Operated Calcium Entry in Rat Neurons. PLOS ONE 6:e19285.

Guner G, Guzelsoy G, Isleyen FS, Sahin GS, Akkaya C, Bayam E, Kotan EI, Kabakcioglu A, Ince-Dunn G (2017) NEUROD2 Regulates Stim1 Expression and Store-Operated Calcium Entry in Cortical Neurons. eneuro 4:ENEURO.0255-0216.2017.

Han S-K, Gottsch ML, Lee KJ, Popa SM, Smith JT, Jakawich SK, Clifton DK, Steiner RA, Herbison AE (2005) Activation of gonadotropin-releasing hormone neurons by kisspeptin as a neuroendocrine switch for the onset of puberty. The Journal of Neuroscience 25:11349-11356.

Hartmann J, Karl RM, Alexander RP, Adelsberger H, Brill MS, Rühlmann C, Ansel A, Sakimura K, Baba Y, Kurosaki T, Misgeld T, Konnerth A (2014) STIM1 controls neuronal $\mathrm{Ca}^{2+}$ signaling, mGluR1-dependent synaptic transmission, and cerebellar motor behavior. Neuron 82:635-644.

Just S et al. (2018) Treatment with HC-070, a potent inhibitor of TRPC4 and TRPC5, leads to anxiolytic and antidepressant effects in mice. PLOS One 13:e0191225.

Kelly MJ, Rønnekleiv OK (2012) Membrane-initiated actions of estradiol that regulate reproduction, energy balance and body temperature. Frontiers in Neuroendocrinology 33:376-387.

Kelly MJ, Qiu J, Rønnekleiv OK (2018) TRPCing around the hypothalamus. Frontiers in Neuroendocrinology $51: 116-124$.

Kuohung W, Kaiser UB (2006) GPR54 and KiSS-1: role in the regulation of puberty and reproduction. Reviews in Endocrine and Metabolic Disorders 7:257-263.

Lehman MN, Coolen LM, Goodman RL (2010) Minireview: kisspeptin/neurokinin B/dynorphin (KNDy) cells of the arcuate nucleus: a central node in the control of gonadotropin-releasing hormone secretion. Endocrinology 151:3479-3489.

Livak KJ, Schmittgen TD (2001) Analysis of relative gene expression data using real-time quantitative PCR and the $2^{-\triangle \Delta C T}$ method. Methods 25:402-408.

Madisen L et al. (2012) A toolbox of Cre-dependent optogenetic transgenic mice for light-induced activation and silencing. Nature Neuroscience 15:793-802.

Mayer C, Acosta-Martinez M, Dubois SL, Wolfe A, Radovick S, Boehm U, Levine JE (2010) Timing and completion of puberty in female mice depend on estrogen receptor $\alpha$-signaling in kisspeptin neurons. 
bioRxiv preprint doi: https://doi.org/10.1101/2020.09.09.289017; this version posted April 1, 2021. The copyright holder for this preprint (which

was not certified by peer review) is the author/funder, who has granted bioRxiv a license to display the preprint in perpetuity. It is made available under aCC-BY 4.0 International license.

Proceedings of the National Academy of Sciences 107:22693-22698.

Moccia F, Zuccolo E, Soda T, Tanzi F, Guerra G, Mapelli L, Lodola F, D’Angelo E (2015) Stim and Orai proteins in neuronal $\mathrm{Ca}^{2+}$ signaling and excitability. Frontiers in Cellular Neuroscience 9:153.

Nagae M, Uenoyama Y, Okamoto S, Tsuchida H, Ikegami K, Goto T, Majarune S, Nakamura S, Sanbo M, Hirabayashi M, Kobayashi K, Inoue N, Tsukamura H (2021) Direct evidence that KNDy neurons maintain gonadotropin pulses and folliculogenesis as the $\mathrm{GnRH}$ pulse generator. Proceedings of the National Academy of Sciences 118:e2009156118.

Navarro VM (2020) Metabolic regulation of kisspeptin — the link between energy balance and reproduction. Nature Reviews Endocrinology 16:407-420.

Navarro VM, Gottsch ML, Chavkin C, Okamura H, Clifton DK, Steiner RA (2009) Regulation of gonadotropinreleasing hormone secretion by kisspeptin/dynorphin/neurokinin B neurons in the arcuate nucleus of the mouse. The Journal of Neuroscience 29:11859-11866.

Navarro VM, Castellano JM, McConkey SM, Pineda R, Ruiz-Pino F, Pinilla L, Clifton DK, Tena-Sempere M, Steiner RA (2011) Interactions between kisspeptin and neurokinin B in the control of GnRH secretion in the female rat. American Journal of Physiology: Endocrinology and Metabolism 300:E202-E210.

Nestor CC, Kelly MJ, Rønnekleiv OK (2014) Cross-talk between reproduction and energy homeostasis: central impact of estrogens, leptin and kisspeptin signaling. Hormone Molecular Biology and Clinical Investigation 17:109-128.

Nestor CC, Qiu J, Padilla SL, Zhang C, Bosch MA, Fan W, Aicher SA, Palmiter RD, Rønnekleiv OK, Kelly MJ (2016) Optogenetic stimulation of arcuate nucleus Kiss1 neurons reveals a steroid-dependent glutamatergic input to POMC and AgRP neurons in male mice. Molecular Endocrinology 30:630-644.

Nguyen N, Biet M, Simard É, Bèliveau É, Francoeur N, Guillemette G, Dumaine R, Grandbois M, Boulay G (2013) STIM1 participates in the contractile rhythmicity of HL-1 cells by moderating T-type $\mathrm{Ca}^{2+}$ channel activity. Biochimica et Biophysica Acta 1833:1294-1303.

Niswender CM, Conn PJ (2010) Metabotropic glutamate receptors: physiology, pharmacology, and disease. Annual Review of Pharmacology and Toxicology 50:295-322.

Oh-hora M, Yamashita M, Hogan PG, Sharma S, Lamperti E, Chung W, Prakriya M, Feske S, Rao A (2008) 
Dual functions for the endoplasmic reticulum calcium sensors STIM1 and STIM2 in T cell activation and tolerance. Nature Immunology 9:432-443.

Okamura H, Tsukamura H, Ohkura S, Uenoyama Y, Wakabayashi Y, Maeda K (2013) Kisspeptin and GnRH pulse generation. Advances in Experimental Medicine and Biology 784:297-323.

Padilla SL, Johnson CW, Barker FD, Patterson MA, Palmiter RD (2018) A neural circuit underlying the generation of hot flushes. Cell Reports 24:271-277.

Park CY, Shcheglovitov A, Dolmetsch R (2010) The CRAC channel activator STIM1 binds and inhibits L-type voltage-gated calcium channels. Science 330:101-105.

Pavez M, Thompson AC, Arnott HJ, Mitchell CB, D'Atri I, Don EK, Chilton JK, Scott EK, Lin JY, Young KM, Gasperini RJ, Foa L (2019) STIM1 Is Required for Remodeling of the Endoplasmic Reticulum and Microtubule Cytoskeleton in Steering Growth Cones. The Journal of Neuroscience 39:5095-5114.

Pfaffl MW (2001) A new mathematical model for relative quantification in real-time RT-PCR. Nucleic Acids Research 29:e45.

Pielecka-Fortuna J, Chu Z, Moenter SM (2008) Kisspeptin acts directly and indirectly to increase gonadotropinreleasing hormone neuron activity and its effects are modulated by estradiol. Endocrinology 149:19791986.

Qiu J, Fang Y, Rønnekleiv OK, Kelly MJ (2010) Leptin excites proopiomelanocortin neurons via activation of TRPC channels. The Journal of Neuroscience 30:1560-1565.

Qiu J, Fang Y, Bosch MA, Rønnekleiv OK, Kelly MJ (2011) Guinea pig kisspeptin neurons are depolarized by leptin via activation of TRPC channels. Endocrinology 152:1503-1514.

Qiu J, Bosch MA, Tobias SC, Grandy DK, Scanlan TS, Rønnekleiv OK, Kelly MJ (2003) Rapid signaling of estrogen in hypothalamic neurons involves a novel G-protein-coupled estrogen receptor that activates protein kinase C. The Journal of Neuroscience 23:9529-9540.

Qiu J, Nestor CC, Zhang C, Padilla SL, Palmiter RD, Kelly MJ, Rønnekleiv OK (2016) High-frequency stimulation-induced peptide release synchronizes arcuate kisspeptin neurons and excited $\mathrm{GnRH}$ neurons. eLife 5:e16246.

Qiu J, Rivera HM, Bosch MA, Padilla SL, Stincic TL, Palmiter RD, Kelly MJ, Rønnekleiv OK (2018a) 
bioRxiv preprint doi: https://doi.org/10.1101/2020.09.09.289017; this version posted April 1, 2021. The copyright holder for this preprint (which

was not certified by peer review) is the author/funder, who has granted bioRxiv a license to display the preprint in perpetuity. It is made available under aCC-BY 4.0 International license.

Estrogenic-dependent glutamatergic neurotransmission from kisspeptin neurons governs feeding circuits in females. eLife $7:$ e35656.

Qiu J, Bosch MA, Meza C, Navarro UV, Nestor CC, Wagner EJ, Rønnekleiv OK, Kelly MJ (2018b) Estradiol protects proopiomelanocortin neurons against insulin resistance. Endocrinology 159:647-664.

Qiu J, Zhang C, Borgquist A, Nestor CC, Smith AW, Bosch MA, Ku S, Wagner EJ, Rønnekleiv OK, Kelly MJ (2014) Insulin excites anorexigenic proopiomelanocortin neurons via activation of canonical transient receptor potential channels. Cell Metabolism 19:682-693.

Qiu J, Bosch MA, Tobias SC, Krust A, Graham S, Murphy S, Korach KS, Chambon P, Scanlan TS, Rønnekleiv OK, Kelly MJ (2006) A G-protein-coupled estrogen receptor is involved in hypothalamic control of energy homeostasis. The Journal of Neuroscience 26:5649-5655.

Roepke TA, Bosch MA, Rick EA, Lee B, Wagner EJ, Seidlova-Wuttke D, Wuttke W, Scanlan TS, Rønnekleiv OK, Kelly MJ (2010) Contribution of a membrane estrogen receptor to the estrogenic regulation of body temperature and energy homeostasis. Endocrinology 151:4926-4937.

Rønnekleiv OK, Qiu J, Kelly MJ (2019) Arcuate Kisspeptin Neurons Coordinate Reproductive Activities with Metabolism. Seminars in Reproductive Medicine 37:131-140.

Ruka KA, Burger LL, Moenter SM (2013) Regulation of arcuate neurons coexpressing kisspeptin, neurokinin B, and dynorphin by modulators of neurokinin 3 and k-opioid receptors in adult male mice. Endocrinology 154:2761-2771.

Ryu C, Jang DC, Jung D, Kim YG, Shim HG, Ryu H-H, Lee Y-S, Linden DJ, Worley PF, Kim SJ (2017) STIM1 regulates somatic $\mathrm{Ca}^{2+}$ signals and intrinsic firing properties of cerebellar Purkinje neurons. The Journal of Neuroscience 37:8876.

Salido GM, Jardin I, Rosado JA (2011) The TRPC ion channels: association with Orai1 and STIM1 proteins and participation in capacitative and non-capacitative calcium entry. Advances in Experimental Medicine and Biology 704:413-433.

Seminara SB, Messager S, Chatzidaki EE, Thresher RR, Acierno JS, Shagoury JK, Bo-Abbas Y, Kuohung W, Schwinof KM, Hendrick AG, Zahn D, Dixon J, Kaiser UB, Slaugenhaupt SA, Gusella JF, O'Rahilly S, Carlton MBL, Crowley WF, Aparicio SAJR, Colledge WH (2003) The GPR54 gene as a regulator of 
puberty. The New England Journal of Medicine 349:1614-1627.

Smith AW, Bosch MA, Wagner EJ, Rønnekleiv OK, Kelly MJ (2013) The membrane estrogen receptor ligand STX rapidly enhances GABAergic signaling in NPY/AgRP neurons: Role in mediating the anorexigenic effects of 17ß-estradiol. American Journal of Physiology: Endocrinology and Metabolism 305:E632E640.

Somasundaram A, Shum AK, McBride HJ, Kessler JA, Feske S, Miller RJ, Prakriya M (2014) Store-Operated CRAC Channels Regulate Gene Expression and Proliferation in Neural Progenitor Cells. The Journal of Neuroscience 34:9107-9123.

Song WJ, Mondal P, Wolfe A, Alonso LC, Stamateris R, Ong BW, Lim OC, Yang KS, Radovick S, Novaira HJ, Farber EA, Farber CR, Turner SD, Hussain MA (2014) Glucagon regulates hepatic kisspeptin to impair insulin secretion. Cell Metabolism 19:667-681.

Stengel A, Wang L, Goebel-Stengel M, Tache Y (2011) Centrally injected kisspeptin reduces food intake by increasing meal intervals in mice. Neuroreport 22:253-257.

Sun Y, Zhang H, Selvaraj S, Sukumaran P, Lei S, Birnbaumer L, Singh BB (2017) Inhibition of L-Type Ca ${ }^{2+}$ channels by TRPC1-STIM1 complex is essential for the protection of dopaminergic neurons. The Journal of Neuroscience 37:3364-3377.

Tolson KP, Marooki N, Wolfe A, Smith JT, Kauffman AS (2019) Cre/lox generation of a novel whole-body Kiss1r KO mouse line recapitulates a hypogonadal, obese, and metabolically-impaired phenotype. Molecular and Cellular Endocrinology 498:110559.

Tolson KP, Garcia C, Yen S, Simonds S, Stefanidis A, Lawrence A, Smith JT, Kauffman AS (2014) Impaired kisspeptin signaling decreases metabolism and promotes glucose intolerance and obesity. Journal of Clinical Investigation 124:3075-3079.

Topaloglu AK, Tello JA, Kotan LD, Ozbek MN, Yilmaz MB, Erdogan S, Gurbuz F, Temiz F, Millar RP, Yuksel B (2012) Inactivating KISS1 mutation and hypogonadotropic hypogonadism. The New England Journal of Medicine 366:629-635.

Tozzi A, Bengtson CP, Longone P, Carignani C, Fusco FR, Bernardi G, Mercuri NB (2003) Involvement of transient receptor potential-like channels in responses to mGluR-I activation in midbrain dopamine 
neurons. European Journal of Neuroscience 18:2133-2145.

729 Wang Y, Deng X, Mancarella S, Hendron E, Eguchi S, Soboloff J, Tang XD, Gill DL (2010) The calcium store sensor, STIM1, reciprocally controls Orai and Cav1.2 channels. Science 330:105-109.

Yuan JP, Zeng W, Huang GN, Worley PF, Muallem S (2007) STIM1 heteromultimerizes TRPC channels to determine their function as store-operated channels. Nature Cell Biology 9:636-645.

Zhang C, Roepke TA, Kelly MJ, Rønnekleiv OK (2008) Kisspeptin depolarizes gonadotropin-releasing hormone neurons through activation of TRPC-like cationic channels. The Journal of Neuroscience 28:4423-4434.

Zhang C, Bosch MA, Rønnekleiv OK, Kelly MJ (2013a) Kisspeptin activation of TRPC4 channels in female GnRH neurons requires $\mathrm{PIP}_{2}$ depletion and cSrc kinase activation. Endocrinology 154:2772-2783. Molecular mechanisms that drive estradiol-dependent burst firing of Kiss1 neurons in the rostral periventricular preoptic area. American Journal of Physiology: Endocrinology and Metabolism 305:E1384-E1397. 


\section{Figure Legends}

FIGURE 1

A1

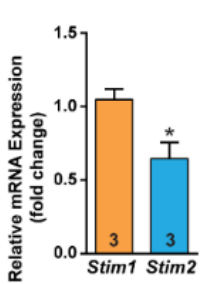

B

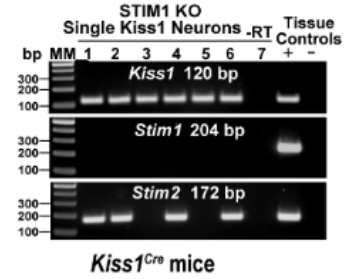

D

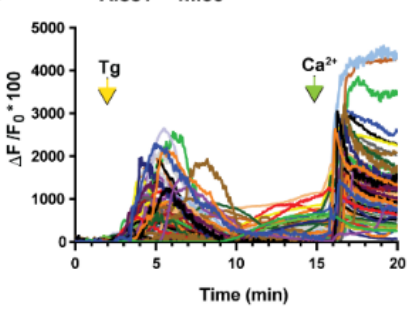

F

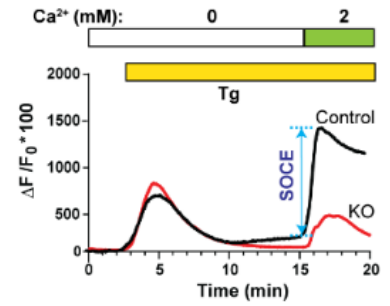

A2

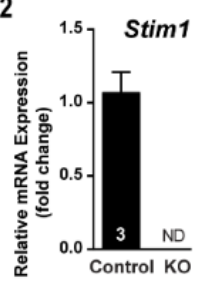

C1
A3

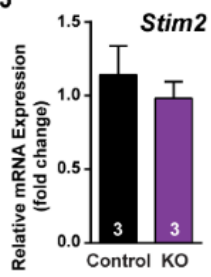

C2 ARH Kiss1-GCaMP6s

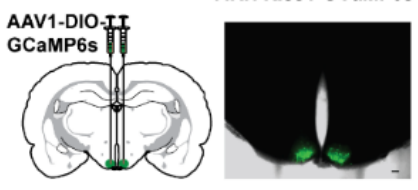

E

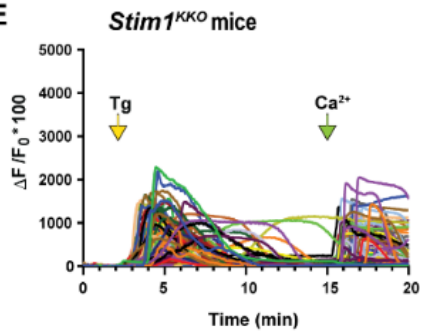

G

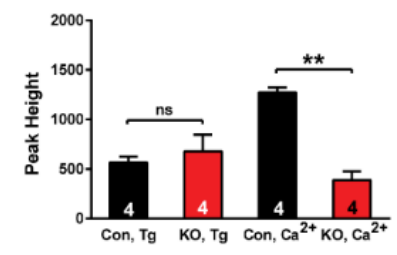

Figure 1. Expression Patterns of Stim1 and 2 in the arcuate Kiss1 neurons. A1-A3, quantitative PCR assay measuring Stim1 and Stim2 in Kiss $1^{\mathrm{ARH}}$ neuronal pools ( $\mathrm{n}=3$ animals, 10 cells in each pool, 4 pools/animal) from Kiss $1^{\text {Cre }}$ control and Stim $1^{k k o}$ female mice ( $\mathrm{n}=3$ animals per group). $\mathbf{A} 1$, comparison between Stim 1 and Stim2 in controls only. Bar graphs represent mean \pm SEM (Unpaired $t$-test $, t_{(4)}=3.079,{ }^{*} p=0.0370$ ); A2, Stim1 was non-detectable (ND) in the STIM1 ${ }^{\mathrm{KKO}}$ neuronal pools (Unpaired $t$-test, $t_{(4)}=7.559,{ }^{* *} p=0.0016$ ); $\mathbf{A 3}$, the Stim2 expression level of Kiss $1^{\text {ARH }}$ neurons was not different between Kiss $1^{\text {Cre }}$ control and Stim $1^{\text {kko }}$ female mice (Unpaired $t$-test, $\left.t_{(4)}=0.7143, p=0.5145\right)$. B, representative gels illustrating mRNA expression of Stim1 and Stim2 in single Kiss $1^{\mathrm{ARH}}$ neurons from Stim $1^{\mathrm{kko}}$ mice. The expected base pair (bp) sizes are Kiss1, 120 bp; Stim1, 204 bp; Stim2, 172 bp. A single neuron was processed without reverse transcriptase (-RT) and RNA extracted 
771 from hypothalamic tissue was used as positive (+, with RT) and negative (-, without RT) tissue controls. MM, molecular marker. $\mathbf{C}$, left, schematic of a coronal section showing the bilateral viral injections in the $\mathrm{ARH}$ with AAV-DIO-GCaMP6s. Right, photomicrograph showing a coronal section confirming targeted bilateral injections of DIO-GCaMP6s into the ARH. D and E, representative traces of GCaMP6s activity based on cytosolic $\mathrm{Ca}^{2+}$ measurements in Kiss $1^{\text {ARH }}$ neurons from Kiss $1^{\text {Cre }}:$ GCaMP6s mice (D) and Stim $1^{\text {kko }}:$ GCaMP6s mice (E). ER Ca ${ }^{2+}$ stores were depleted with $2 \mu \mathrm{M}$ thapsgargin, a SERCA inhibitor, after 20 min of perfusion with aCSF containing $0 \mathrm{mM} \mathrm{Ca}^{2+}$. SOCE was evaluated by substituting the extracellular aCSF containing $0 \mathrm{mM} \mathrm{Ca}^{2+}$ with aCSF containing $2 \mathrm{mM} \mathrm{Ca}^{2+}$. F, averaged traces from $\mathrm{D}$ and $\mathrm{E}$ revealed that deletion of Stim1 in Kiss $1^{\mathrm{ARH}}$ neurons attenuated the store-operated $\mathrm{Ca}^{2+}$ entry (SOCE). G, bar graphs summarizing the effects of depletion of $\mathrm{Ca}^{2+}$ store by $\mathrm{Tg}$ and $\mathrm{Ca}^{2+}$ influx (SOCE) in Kiss $1^{\mathrm{ARH}}$ neurons from Kiss1Cre:GCaMP6s and Stim ${ }^{\mathrm{kko}}: \mathrm{GCaMP6s}$ mice (two-way ANOVA: main effect of treatment $\left(F_{(1,3)}=13.84, p=0.0338\right)$, main effect of time $\left(F_{(1,3)}=5.199, p=\right.$ $0.1069)$ and interaction $\left(\mathrm{F}_{(1,3)}=52.14, p=0.0055\right) ; \mathrm{n}=$ number of slices; post hoc Bonferroni test, ${ }^{* *} p<0.01$, for SOCE; ns = no significant, for depletion of $\mathrm{Ca}^{2+}$ store.

\section{FIGURE 2}

A

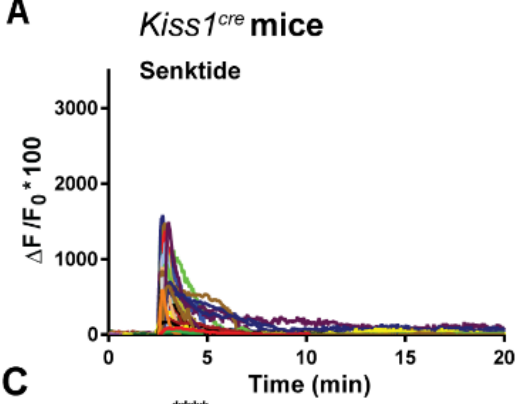

791

792

793

794

795

Figure 2. Senktide-induced increase in $\left[\mathrm{Ca}^{2+}\right]_{\mathrm{i}}$ is augmented by deletion of Stim1 in GCaMP6s-expressing Kiss $1^{A R H}$ neurons from Kiss $1^{\text {Cre }}$ and Stim $1^{k k o}$ mice. A and B, representative traces of senktide-induced $\left[\mathrm{Ca}^{2+}\right]_{\mathrm{i}}$ 
in Kiss $1^{\mathrm{ARH}}$ neurons from Kiss $1^{\mathrm{Cre}}$ (A) and Stim $1^{\mathrm{kKo}}$ (B) mice. Traces represent individual cells within a single slice. C, summary of the potentiation of senktide-induced $\left[\mathrm{Ca}^{2+}\right]_{i}$ by deletion of Stim1. Two-way ANOVA: main effect of treatment $\left(F_{(1,11)}=5.265, p=0.0424\right)$, main effect of time $\left(F_{(19,209)}=42.69, p<0.0001\right)$ and interaction $\left(\mathrm{F}_{(19,209)}=6.486, p<0.0001\right) ; \mathrm{n}=$ number of slices; post hoc Bonferroni test, ${ }^{* \star *} p<0.001 ;{ }^{* *} p<0.01 ;{ }^{*} p<0.05$. D, AUC of Kiss $1^{\mathrm{ARH}}$ neurons from Kiss $1^{\mathrm{Cre}}$ and Stim $1^{\mathrm{kko}}$ mice from C. There was a significant difference (Unpaired $t$-test, $\left.t_{(11)}=2.430,{ }^{*} p=0.0334\right)$ between the two groups.

\section{FIGURE 3}
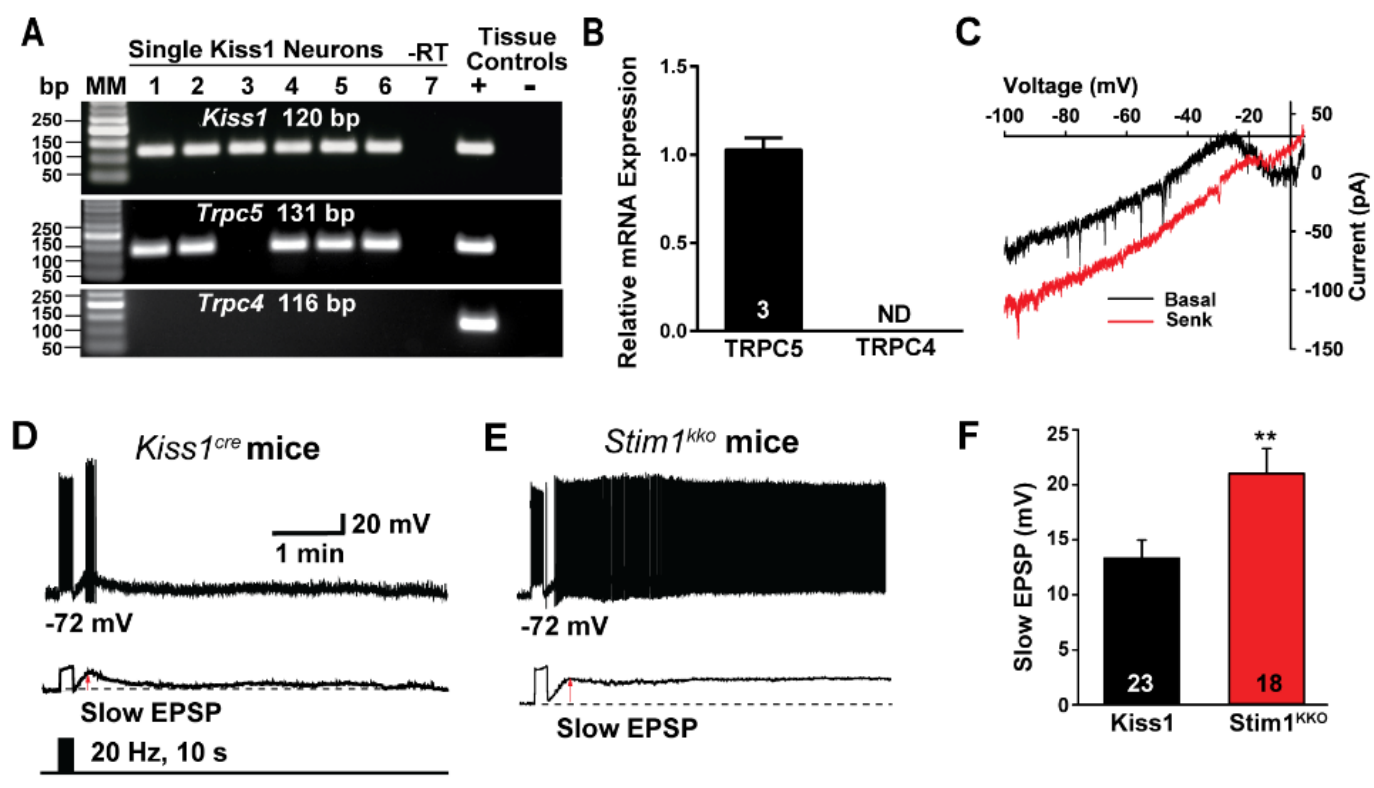

Figure 3. Deletion of Stim1 augments high-frequency optogenetic stimulation-induced slow EPSP

depolarization in Kiss $1^{\text {ARH }}$ neurons. A, representative gel image illustrating the mRNA expression of Trpc5 channel subunit in Kiss $1^{\mathrm{ARH}}$ neurons harvested from female mice. The expected size of PCR products for Kiss1 and Trpc5 are indicated. Trpc4 mRNA was not detected in Kiss $1^{\mathrm{ARH}}$ neurons. MM is the molecular marker; -RT indicates a harvested Kiss1 neuron reacted without RT; + indicates positive tissue control (with RT); - indicates negative tissue control (without RT) using cDNA from mouse medial basal hypothalamic tissue; RT, reverse transcriptase. B, quantitative single cell PCR $(3 \times 10$ cell pools per animal, $\mathrm{n}=3$ animals $)$ verified that $\operatorname{Trpc} 5$ was expressed in Kiss $1^{\text {ARH }}$ neurons, whereas Trpc4 mRNA was not detected (Unpaired $t$-test for the left, $t_{(4)}=15.67$, 
325

326

327

328

329

330

331

332

333

334

335

336

337

338

339

340

341

342

343

344

345

346

347

348

349

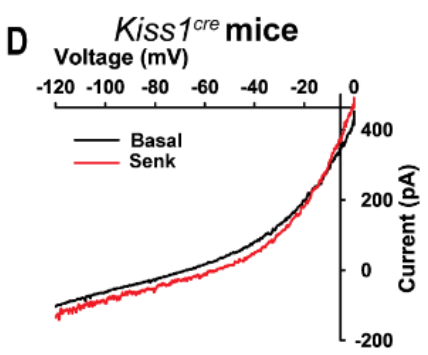

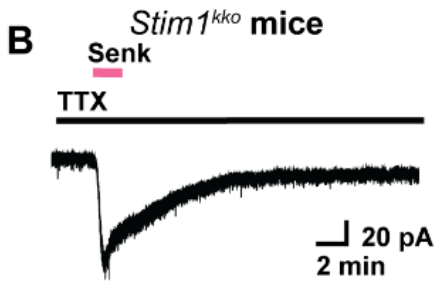

E Stim $1^{k k o}$ mice

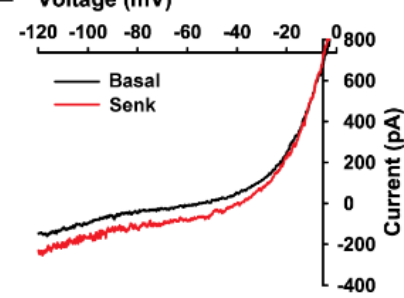

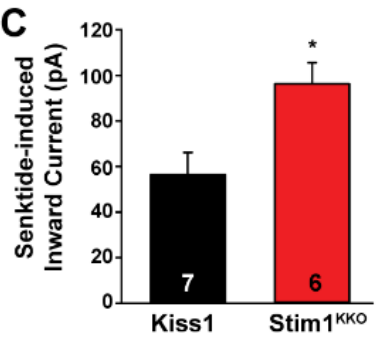

F

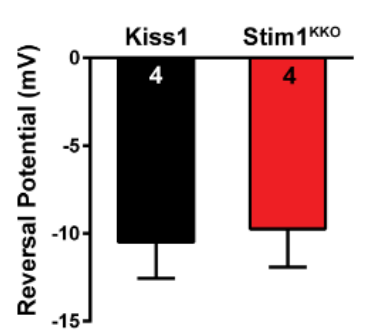

Figure 4. Deletion of Stim1 augments senktide-induced depolarization in Kiss $1^{\mathrm{ARH}}$ neurons. A and B, rapid bath application of senktide $(1 \mu \mathrm{M})$ induced an inward current in the presence of fast sodium channel blockade $(\mathrm{TTX}, 1 \mu \mathrm{M})$ in Kiss $1^{\mathrm{ARH}}$ neurons from Kiss $1^{\text {Cre }}$ and Stim $1^{\mathrm{kko}}$ mice. $\mathrm{V}_{\text {hold }}=-60 \mathrm{mV}$. C, summary of the effects of senktide in Kiss $1^{\mathrm{ARH}}$ neurons from Kiss $1^{\text {Cre }}$ and Stim ${ }^{\text {kKo }}$ mice (Unpaired $t$-test, $t_{(11)}=2.929,{ }^{*} p=$ 0.0137). Data points represent the mean \pm SEM. Cell numbers are indicated. $\mathbf{D}$ and $\mathbf{E}$, the $\mathrm{I}-\mathrm{V}$ relationship before and during the peak response of senktide (Senk) in Kiss $1^{\mathrm{ARH}}$ neurons from Kiss $1^{\mathrm{Cre}}$ (D) and Stim $1^{\text {kko }}$ (E) mice indicated that the reversal potential of the nonselective cation current was $\sim-10 \mathrm{mV}$. F, summary of the reversal potentials of the senktide-induced cation current recorded in Kiss $1^{\text {ARH }}$ neurons from Kiss $1^{\text {Cre }}$ and Stim $1^{\text {kko }}$ mice. Bar graphs represent the mean \pm SEM (unpaired two-tailed $t$ test, $t_{(6)}=0.2503, p=0.8107$ ). 
FIGURE 5

353

354

355

356

357

358

359

360

361

362

363

364

365

366

367

368

369

370

$37^{\circ}$

372

373

374

375

376

377

378
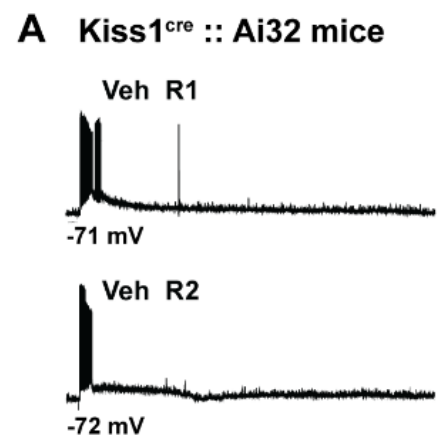

D Stim $1^{\text {kko }}$ mice

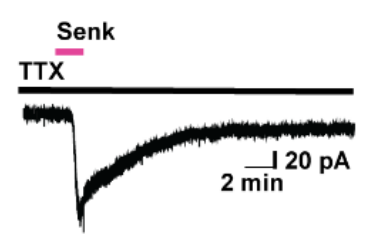

B
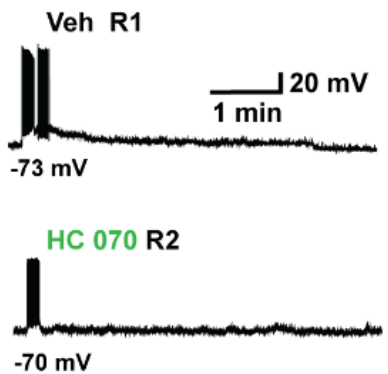

E

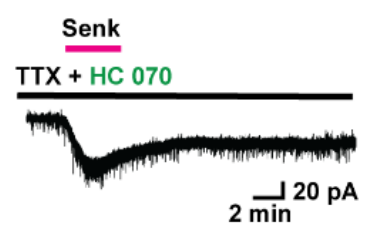

C

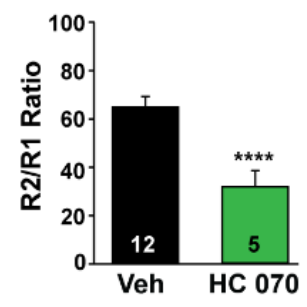

$\mathbf{F}$

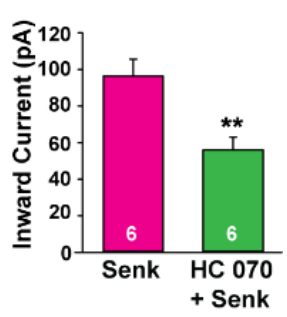

Figure 5. Stim1 deletion augments senktide-induced Kiss ${ }^{A R H}$ neuronal excitability through TRPC channel activation. A-C, high frequency photo-stimulation - induced slow EPSP in Kiss $1^{\mathrm{ARH}}$ neurons from Kiss $1^{\text {Cre }:: A i 32 ~ m i c e ~ i s ~ a n t a g o n i z e d ~ b y ~ T R P C 5 ~ c h a n n e l ~ b l o c k e r . ~ A-B, ~ r e p r e s e n t a t i v e ~ t r a c e s ~ o f ~ h i g h-f r e q u e n c y ~}$ optogenetic stimulation-induced slow EPSPs in the absence (A) or presence (B) of TRPC4/5 channel blocker HC $070(100 \mathrm{nM})$. C, summary of the effects of HC 070 on the slow EPSP (Un-paired t-test, $t_{(15)}=4.122,{ }^{\star \star * *} p$ = 0.0009). D-F, Stim1 deletion augments senktide-induced inward current, which is antagonized by the TRPC5 channel blocker. D-E, representative traces of senktide $(1 \mu \mathrm{M})$-induced inward current in Stim $1^{\text {kko }}$ neurons perfused with TTX $(1 \mu \mathrm{M})$ in the absence $(\mathrm{D})$ or presence $(\mathrm{E})$ of TRPC4/5 blocker HC 070 (100 nM). F, summary of the effects of HC 070 on the senktide-induced inward current (Un-paired t-test, $t_{(10)}=3.457,{ }^{* *} p=0.0062$ ). Data points represent the mean \pm SEM. Cell numbers are indicated. 


\section{FIGURE 6}

380

381

382

383

384

385

386

387

388

389
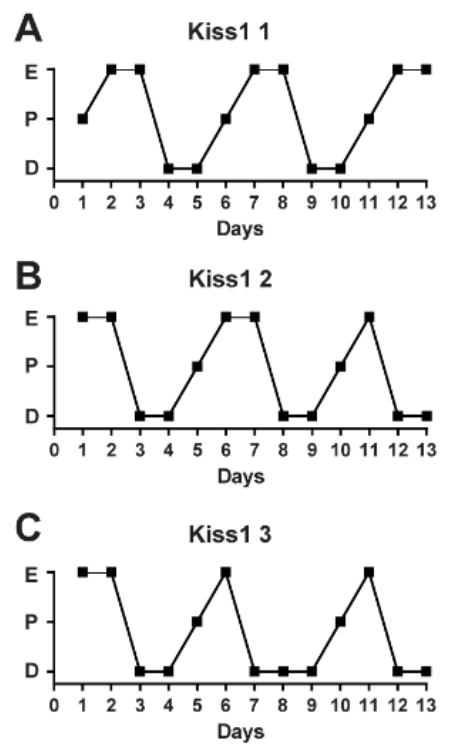
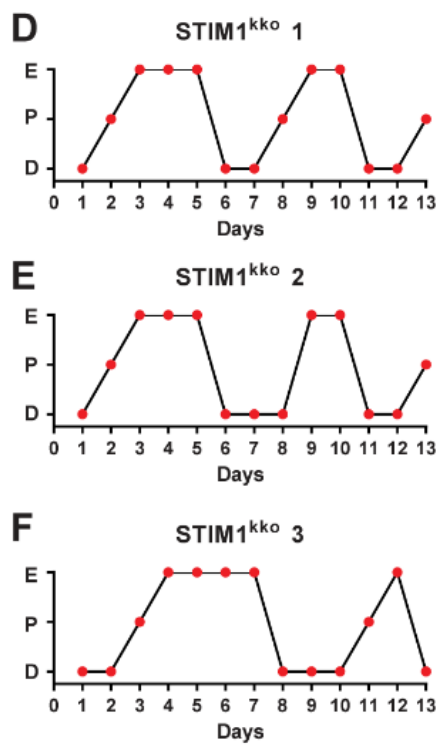

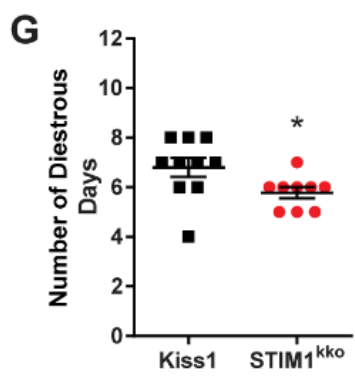

H

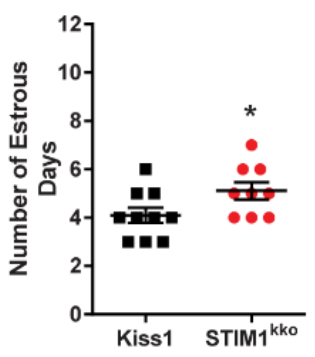

Figure 6. Stim1 ${ }^{k k o}$ mice exhibit more estrous days. A-F, representative estrous cycle data from three representative control Kiss $1^{\text {Cre }}$ and three Stim $1^{k k o}$ mice over a thirteen-day period. Vaginal lavage was done daily at 0930 h, and cell cytology was observed and recorded as Diestrus (D), Proestrus (P) or Estrus (E). Summary data for the number of Diestrous days $(\mathbf{G})$ and Estrous days $(\mathbf{H})$ during the 13 day period was compared between Kiss $1^{\text {Cre }}(n=10)$ and Stim $1^{\text {kko }}$ mice $(n=9)$ (unpaired, two-tailed t test for $G, t_{(17)}=2.215,{ }^{*} p$ $=0.0407$; unpaired two-tailed t-test for $\left.\mathrm{H}, t_{(17)}=2.151,{ }^{*} \mathrm{p}=0.0461\right)$. 
398

399

900

901

902

903

904

905

906

907

908

909

910

911

912

913

914

915

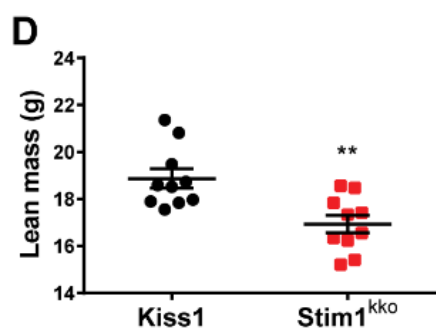

B
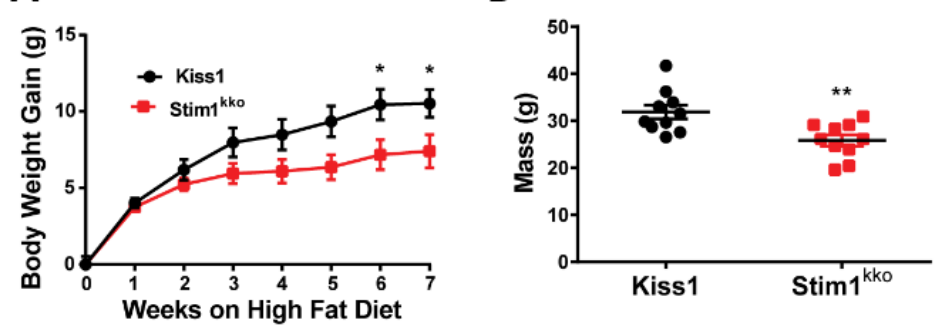

C

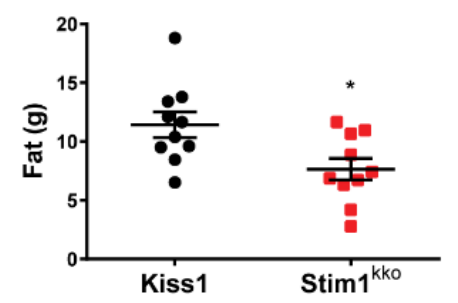

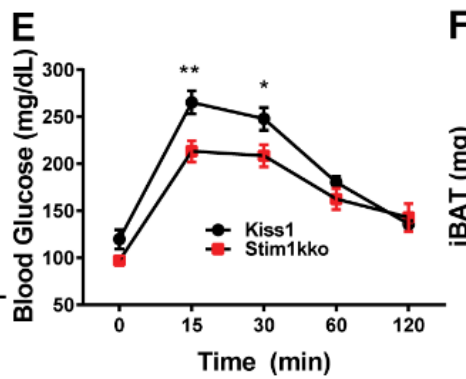

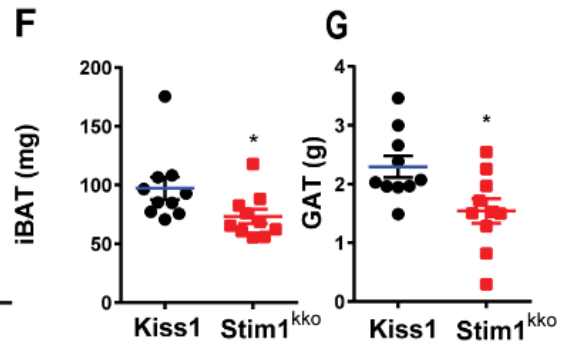

Figure 7. Ablation of Stim1 in Kiss1 neurons attenuates body mass, fat, and lean in mice on a high fat diet. Stim $1^{\mathrm{k} o}$ and Kiss $1^{\mathrm{Cre}}$ littermate control females were ovariectomized and fed a high fat diet (HFD; 45\% kcal from fat) for seven weeks. A, body-weight gain measured once a week for seven weeks. The high fat diet caused significant weight gain in both groups relative to their baseline with the Kiss $1^{\text {Cre }}$ females gaining significantly more weight by 6 weeks [two-way ANOVA: main effect of treatment $\left(F_{(1,18)}=3.839, p=0.0657\right)$, main effect of time $\left(F_{(7,126)}=98.07, p<0.0001\right)$ and interaction $\left(F_{(7,126)}=4.645, p=0.0001\right)$; Kiss1 control, $n=10$, Stim $1^{\text {kko }}$, $\mathrm{n}=10$; post hoc Bonferroni test, ${ }^{*} \mathrm{p}<0.05$ ]. B-D, mass $(\mathrm{B})$, total body fat $(\mathrm{C})$ and lean mass $(\mathrm{D})$ measured by an EchoMRI Whole Body Composition Analyzer. Lean mass did not include bone and fluids within organs. The difference in mass (B), body fat (C) and lean mass (D) between the groups was significantly different by 6 weeks on high fat diet (unpaired, two-tailed t-test for $\mathrm{B}, t_{(18)}=3.222,{ }^{* *} \mathrm{p}=0.0047$; unpaired two-tailed $\mathrm{t}$ test for $\mathrm{C}, t_{(18)}=$ 2.662, ${ }^{*} p=0.0159$; unpaired, two-tailed $t$ test for $\left.D, t_{(18)}=3.489,{ }^{*} p=0.0026\right)$. $E$, six weeks after high fat diet, there was a significant difference in GTTs between the two groups (two-way ANOVA: main effect of treatment $\left(F_{(1,9)}=6.282, p=0.0335\right)$, main effect of time $\left(F_{(4,36)}=88.01, p<0.0001\right)$ and interaction $\left(F_{(4,36)}=3.527, p=\right.$ 0.0158); Kiss ${ }^{\text {Cre }}, \mathrm{n}=6$, Stim $1^{k \mathrm{kko}}, \mathrm{n}=5$; post hoc Bonferroni test, $\left.{ }^{* *} \mathrm{p}<0.01,{ }^{*} \mathrm{p}<0.05\right) . \quad \mathbf{F}$ and $\mathbf{G}$, both interscapular brown adipose tissue (BAT) and perigonadal adipose tissue (GAT) mass of Stim $1^{k k o}$ were lighter 
923 than that of Kiss $1^{\text {Cre }}$ mice on a fat diet after eight weeks (unpaired, two-tailed t test for iBAT, $t_{(18)}=2.127,{ }^{*} p=$

9240.0475 ; unpaired two-tailed t-test for GAT, $\left.t_{(18)}=2.711,{ }^{*} \mathrm{p}=0.0143\right)$.

925

926

927

928

929

930

931

932

933

934

935

936

937

938

939

940

941

942

943

944

945

946

947

948

949

\section{FIGURE 8}

A. Store Operated

B. Receptor Operated

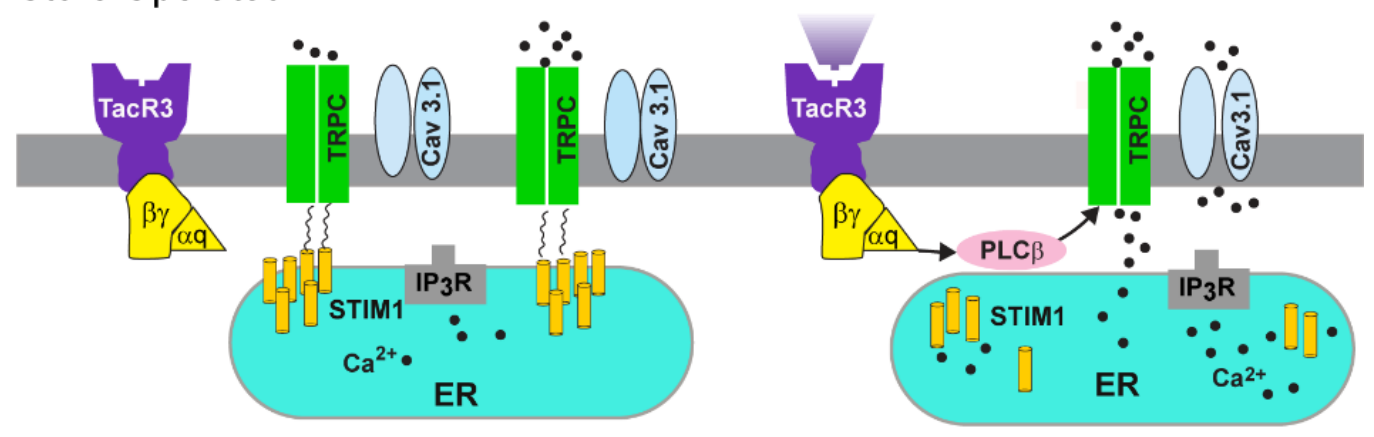

Figure 8. A cellular model of STIM1 affecting NKB activation of TRPC5 channels in Kiss ${ }^{\mathrm{ARH}}$ neurons. A, Store-operated calcium entry (SOCE) is a conserved mechanism by which the depletion of the endoplasmic reticulum (ER) is conveyed to calcium-permeable channels at the plasma membrane (PM), triggering calcium influx from the extracellular space and into the cell cytosol. A physiological mechanism responsible for the activation of SOCE results from the stimulation of G-protein coupled receptors associated with the inositoltriphosphate (IP3) and phospholipase C cascade, resulting in the release of calcium from ER, via the IP3 receptor (IP3R). Under physiological stress and in the absence of $\mathrm{E}_{2}$, stromal interaction molecule 1 (STIM1) interacts with TPRC5 channels thereby engaging these $\mathrm{Ca}^{2+}$ channels as store-operated channels, which are activated with endoplasmic reticulum (ER) depletion of $\mathrm{Ca}^{2+}$. B, however, under physiological conditions in reproductively active females, in which $E_{2}$ down-regulates the expression of STIM1, TRPC 5 channels are converted to receptor-operated channels in Kiss $1^{A R H}$ neurons. Neurokinin $B(N K B)$ binds to its receptor (TacR3) to activate Gaq - PLC $\beta$ signaling cascade to facilitate TPRC 5 channel opening, generating a robust inward $\mathrm{Na}^{+} / \mathrm{Ca}^{2+}$ current to depolarize Kiss $1^{\mathrm{ARH}}$ neurons, activating T-type calcium (Cav3.1) channels to greatly increase Kiss $1^{\mathrm{ARH}}$ neuronal excitability. 
950

951

952

953

954

955

956

957

958

959

960

961

962

963

964

965

966

967

968

969

970

971

972

97

97

975

Stim2 (STIM2)

NM_001363348

Stim2 (STIM2) $)^{b}$

NM_001363348

NM_008084

Gapdh (GAPDH) ${ }^{b}$

Trpc4 (TRPC4)a,b

NM_016984

$\operatorname{Trpc5}\left(\right.$ TRPC5) ${ }^{\mathrm{a}}$

NM_009428

$\operatorname{Trpc5}$ (TRPC5) $^{\mathrm{b}}$

NM_009428

Accession

aprimers for SCRT-PCR.

bprimers for GPCR.
Primer

Product

Location (nt) Length (bp)

120

64-80 (exon 1)

167-183 (exon 2)

797-816 (exon 2)

204

59

981-1000 (exon 3)

821-839 (exon 2)

135

937-955 (exon 3)

620-638 (exon 2)

172

773-791 (exon 4)

1784-1803 (exon 11)

131

60

$-3.4390 .993$

95

1895-1914 (exon 12)

689-706 (exon 4)

93

764-781 (exon 5)

1888-1907 (exon 6)

116

60

$\begin{array}{lll}-3.318 & 0.940 \quad 100\end{array}$

1984-2003 (exon 7)

2206-2227 (exon 6) 131

63

2315-2336 (exon 7)

734-753 (exon 2)

118

60

$-3.1610 .953 \quad 100$

832-851 (exon 3)

Figure 2-video supplement 1. Neurokinin B receptor agonist senktide induces $\left[\mathrm{Ca}^{2+}\right]_{i}$ increase in Kiss $1^{\text {ARH }}$ neurons expressing GCaMP6s. Imaging of transient $\mathrm{Ca}^{2+}$ changes in an arcuate slice using spinning disk confocal microscopy. Fluorescence intensity was measured over 20 minutes, before and after application 
980 of senktide $(1 \mu \mathrm{M})$. The period represented is 20 minutes.

982 Figure 3-video supplement 1. High frequency photo-stimulation induces a slow excitatory postsynaptic

983 potential (slow EPSP). Slow EPSP was induced by a $10-\mathrm{s} 20 \mathrm{~Hz}$ photostimulation (light intensity $0.9 \mathrm{~mW}$ and

984 pulse duration, $10 \mathrm{~ms}$ ) in a ChR2-expressing Kiss $1^{\mathrm{ARH}}$ neuron in a slice from a $\mathrm{Kiss} 1^{\mathrm{Cr} e}:: \mathrm{Ai32}$ mouse. The period 985 represented is 1 minute, 34 seconds. 